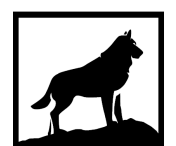

Michigan Technological

1 в 8 5 University
Michigan Technological University Digital Commons @ Michigan Tech

POTENTIAL ENVIRONMENTAL AND SOCIAL INFLUENCES ON SCHOOLCHILDREN'S HEALTH AND NUTRION IN GUIBA, BURKINA FASO

Kristine Nachbor

Michigan Technological University, kmnachbo@mtu.edu

Copyright 2016 Kristine Nachbor

Recommended Citation

Nachbor, Kristine, "POTENTIAL ENVIRONMENTAL AND SOCIAL INFLUENCES ON SCHOOLCHILDREN'S HEALTH AND NUTRION IN GUIBA, BURKINA FASO", Open Access Master's Report, Michigan Technological University, 2016.

https://doi.org/10.37099/mtu.dc.etdr/135

Follow this and additional works at: https://digitalcommons.mtu.edu/etdr

Part of the Life Sciences Commons 


\title{
POTENTIAL ENVIRONMENTAL AND SOCIAL INFLUENCES ON SCHOOLCHILDREN'S HEALTH AND NUTRION IN GUIBA, BURKINA FASO
}

\section{By}

Kristine M. Nachbor

\begin{abstract}
A REPORT
Submitted in partial fulfillment of the requirements for the degree of MASTER OF SCIENCE

In Biological Sciences
\end{abstract}

MICHIGAN TECHNOLOGICAL UNIVERSITY

2016

(C) 2016 Kristine M. Nachbor 
This report has been approved in partial fulfillment of the requirements for the Degree of MASTER OF SCIENCE in Biological Sciences.

Department of Biological Sciences

Report Advisor: Dr. Casey Huckins

Committee Member: Dr. Kari Henquinet

Committee Member: $\quad$ Dr. Mark Rouleau

Department Chair: Dr. Shekhar Joshi 


\section{TABLE OF CONTENTS}

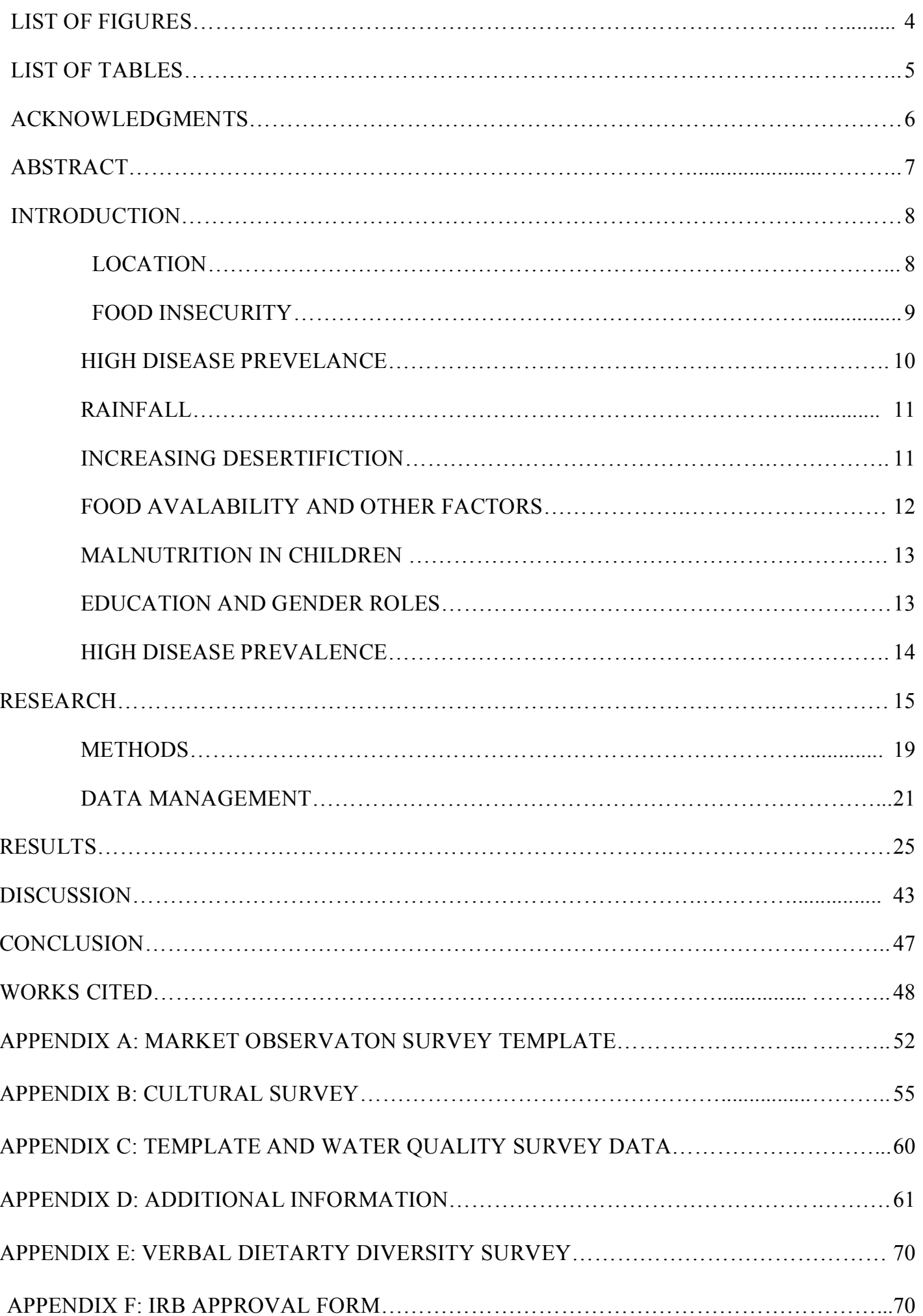




\section{LIST OF FIGURES}

Figure 1. Diagram of temperature, rainfall, and agricultural seasons............. 10

Figure 2. Diagram of potential influencing factors on malnutrition................. 17

Figure 3. Drawing that provides difference between compound and household.....28

Figure 4. Number of food vendors present in the market from $2013-2015 \ldots \ldots \ldots \ldots . . .29$

Figure 5. Number of vendors selling roots, tubers, nuts from $2013-2015 \ldots \ldots \ldots \ldots 31$

Figure 6. Number of vendors selling other vegetables by from 2013-2015......... 32

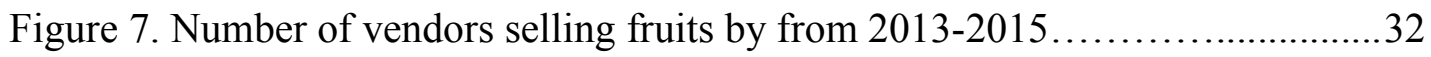

Figure 8. Number of vendors selling green leafy vegetables from 2013-2015 _..... 33

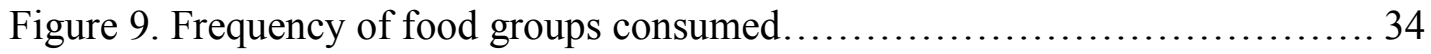

Figure 10. Percentage of low, medium and high DDS for October................. 36

Figure 11. Percentage of low, medium and high DDS for April................... 37

Figure 12. Petrifilms with varying levels of fecal bacteria................................. 42 


\section{LIST OF TABLES}

Table 1. Food item classified by food group.............................. 22

Table 2. Percentage of individuals within each socio-demographic criteria......... 26

Table 3. DDS by Month compared to Socio-demographic characteristics...........39

Table 4. Drinking water source contamination near the school grounds............43

Table 5. Percentage of Males (M) and Females (F) in school......................68

Table 6. Number of students by sex enrolled in 8 th grade...................... 69 


\section{ACKNOWLEDGMENTS}

It is impossible to articulate my appreciation for the aid that I received from my advisor. Casey Huckins, you have been there throughout my graduate career in the Peace Corps Masters International Program at Michigan Technological University. Serving in Burkina Faso had many difficulties including staying connected, however, Casey ensured that I had the resources I needed throughout my two years of field research. My report could not have been completed without the presence of my irreplaceable committee. Each of the members of my committee played a specific role. Kari helped me design a survey and navigate IRB approval. Mark served as a wonderful resource for research synthesis and data analysis when I returned to the USA.

The fellow Peace Corps volunteers who became my dear friends provided me with moral support during the most difficult times. When my research came crashing down and my petrifilms magically disappeared from the office where I was storing them, it was my friends that helped me laugh when I felt like crying. They were always there to listen to my research ideas and challenged me to ask different questions. I want to specifically thank Patrick Williams and Amy Stiles who provided extra encouragement throughout my project.

Burkina is known as the land of upright people and I truly felt at home among some of the kindest people in the world. The staff at the Peace Corps Bureau, my village, and other natives from Burkina Faso invited me to learn about their culture and environment by graciously hosting me in their country and homes for two years. These people helped me learn along side them and opened my eyes to the reality of life in Burkina Faso.

I must thank the people who were my foundation and support throughout my life: my family. My parents have always emphasized the importance of education and curiosity; it was this desire to learn that initially brought me to Burkina Faso. My two sisters offered support and were always there to listen when I was missing home. Thank you, without my family I would not be where I am today. Merci et Barkka. 


\begin{abstract}
Malnutrition continues to be an epidemic problem in sub-Saharan Africa. The degree of malnutrition depends on many factors including prevalence of bacterial and parasitic diseases especially those in water sources, level of education, level of hygienic practices, cultural customs, seasonal and climatic conditions, food production and availability, and daily food intake. This study sought to describe the prevalence of different factors' that may be associated with health in the commune of Guiba, Burkina Faso while also examining the dietary diversity scores (DDS) among schoolchildren attending secondary school in Guiba.

Dietary diversity scores (DDS) are a measure of the number of food groups consumed by an individual. DDS serve as a proxy for nutritional adequacy. DDS was calculated from data collected using a series of related surveys over the months of October 2014 and April 2015 which asked individuals to perform a 24-hour recall of their food intake. A qualitative verbal survey was also conducted in May 2015 to determine the relation of cultural, educational, and hygienic practices to individual DDS. Production, price, and availability of different food items throughout a two year time period (August 2013 to June 2015) were described using monthly market observations at Guiba's local market. Finally, a separate assessment of water quality surveys were performed during the end of dry season (June 2015) and at the beginning of rainy season (July 2015) to understand the prevalence of waterborne pathogens in water sources used by the schoolchildren. Water quality was tested at 10 different water sources within a five-kilometer radius of Guiba's secondary school using $3 \mathrm{M}^{\mathrm{TM}}$ Petrifilm ${ }^{\mathrm{TM}}$ Count Plates that were analyzed to provide a measure of microbial counts.

From the findings, the mean DDS of the individual schoolchildren surveyed in Guiba was low suggesting overall poor dietary diversity. The basic diet consisted of cereals such as millet, corn, and sorghum. Socio-demographic factors, such as the education level of the mother appear to be related to DDS. Water quality tests showed that eighty percent of water sources near the secondary school in the commune of Guiba were contaminated with fecal bacteria. These descriptions of the different environmental, social, and cultural influences may be potential improvement opportunities for health intervention, including food aid, in the future.
\end{abstract}




\section{INTRODUCTION}

Malnutrition continues to be an epidemic problem in sub-Saharan Africa [26]. The effects of malnutrition in children are well documented; malnutrition decreases physical capacity and cognitive development while concurrently increasing susceptibility to disease, stunting, and anemia $[27,36,37,56]$. Although, the nutritional status of schoolchildren in rural Burkina Faso is poorly documented, available data suggests that in Burkina Faso micronutrient deficiencies are high among children under five (88\%) and are linked to over thirty percent of all children's deaths [46, 49]. Micronutrient deficiencies are also highly prevalent in schoolchildren older than five in Ouagadougou, the capital city of Burkina Faso [52]. However, malnutrition is still more pervasive in rural areas of developing countries than urban ones $[26,52]$. Due to the large number of people subsistence farming (92\%), the school children in rural Burkina Faso are significantly impacted by the increasing desertification and food insecurity within the country [37, 49]. This report seeks to examine the prevalence of environmental (e.g. bacterial and parasitic diseases especially those in water sources, seasonal and climatic conditions, food production and availability) and social variables (e.g. level of education, level of hygienic practices, cultural customs, and daily food intake) in conjunction with a description of the nutritional status of schoolchildren in a rural commune called Guiba, Burkina Faso.

\section{Location}

Malnutrition continues to be pervasive in rural areas of developing countries [26] such as the commune of Guiba located in Burkina Faso. Guiba is situated between $11^{\circ} 43^{\prime} 20^{\prime \prime}$ and $11^{\circ} 32^{\prime} 30^{\prime \prime}$ latitude north and $1^{\circ} 5^{\prime} 5^{\prime \prime}$ ' and $1^{\circ} 16^{\prime} 40^{\prime \prime}$ longitude west [5, 52]. Guiba, Burkina Faso displays characteristics of a large village in that it has multiple water pumps and electricity in the center of village [5]. Yet, Guiba is more rural than Ouagadougou (100 kilometers away) and the regional capital called Manga (12 kilometers away) [5]. Teaching in a rural secondary school in the commune of Guiba facilitated observation of schoolchildren and lead to the initial inquiry about schoolchildren's health and nutritional status. Guiba provided a prime location to study the connections between environmental and social indicators of schoolchildren's 
nutritional status due to it being a moderate sized town displaying characteristics of both a city and rural village.

In Guiba, like most of Burkina, there is little topographic diversity in the landscape; it rests on a savannah plateau with plains dominating and consisting mostly of brush, fields, and scattered trees [12]. However only one percent of the land in the commune of Guiba is untouched savannah, ninety percent of the landscape is agricultural land as a result of the majority of the population being subsistence farmers [5]. An estimated ninety two percent of Burkina Faso's population relies on subsistence agriculture to survive [49].

\section{Food Insecurity}

High poverty rates along with Burkina Faso being landlocked make it more susceptible to economic shocks such as high food prices. These high poverty rates rank Burkina Faso among the poorest countries in the world; Burkina Faso was ranked 183 out of 186 on UNDP's Human Development Index in 2013 [46]. In 2012, Burkina Faso had a poverty rate of forty six percent and eighty eight percent of people were living on less than two dollars per day. Per capita income was estimated at $\$ 660$ with the unemployment rate at seventy seven percent [49]. As one of the poorest countries in the world, Burkina Faso has the largest risk factor for malnutrition; poverty [26]. Poverty has been linked to high food insecurity that consequently increases health challenges [46]. 


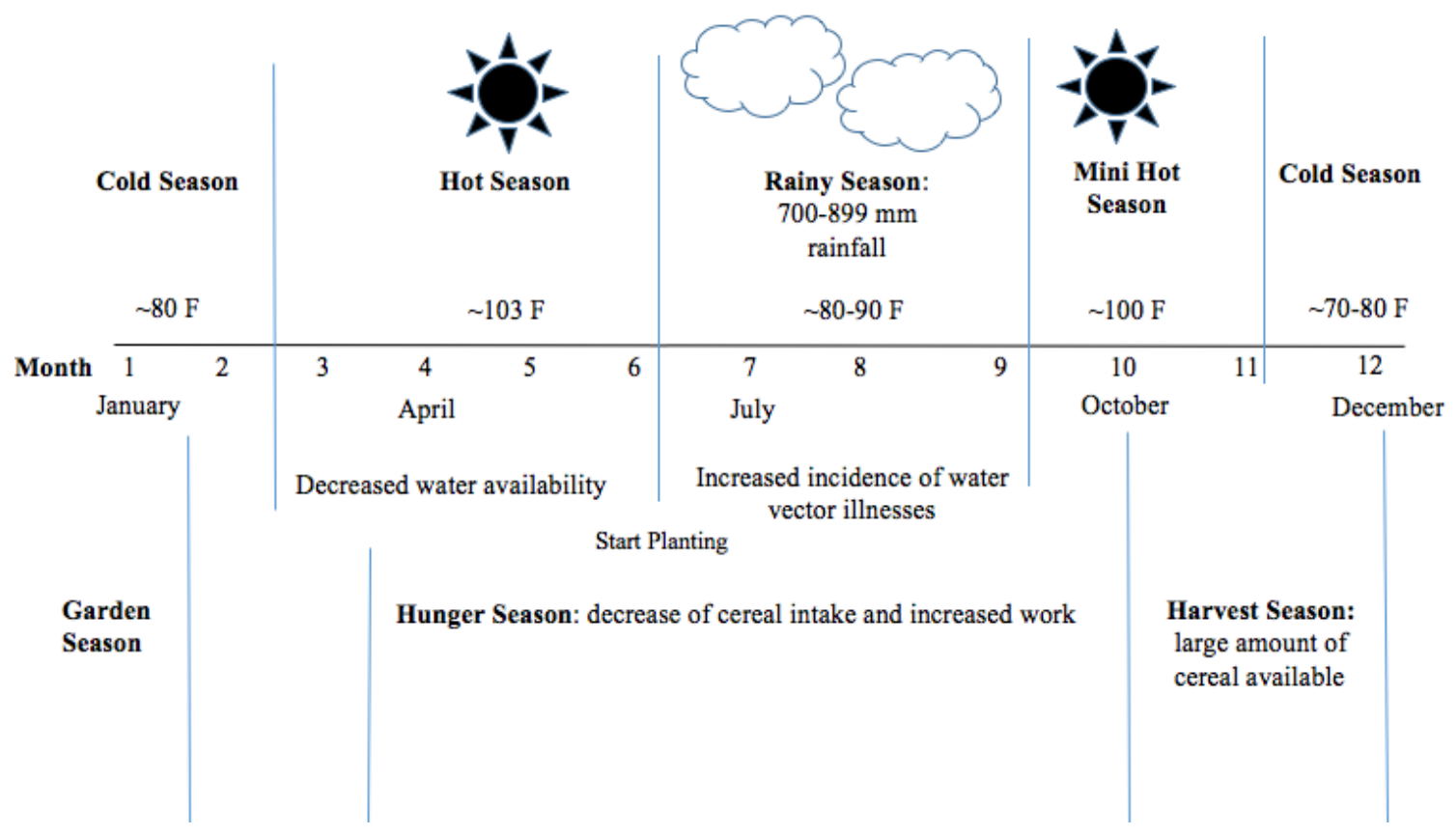

Figure 1. Diagram of seasonality, temperature, and activities by month in Guiba, Burkina Faso

Rural communities, such as Guiba, are the best study sites for nutritional studies because they are more greatly affected by the burden of food shortage due to seasonality since they depend on the yearly harvest of a single crop after rainy season [37]. Many households in Burkina Faso experience food insecurity during lean season, June-August, and very poor families do not have access to staple cereals during this time period [46]. During the time that I was conducting my research in Guiba (2013 to 2015) the months with low cereal were during the middle of hot season (April) where temperatures averaged around 103 degrees Fahrenheit. In Guiba this time, before the harvest, is known as "hunger season" [personal observations]. Hunger season is characterized by a decrease in food availability along with an increase of intense agricultural work [37] (Figure 1). The effects of "hunger season" amplify the impacts of malnutrition by increasing food insecurity, which is already chronic in Burkina Faso. According to the Global Hunger Index food insecurity in Burkina Faso is ranked at 65 out of 76 [46]. An estimated 2 million people were food insecure in 2013 [49]. 


\section{Rainfall}

Since subsistence farming is an integral part of individuals' lives, the yearly harvest is situated around the two distinct seasons-wet and dry (Figure 1) [37]. The wet season occurs for approximately four months between June and September [38]. The region of Guiba receives $700-899 \mathrm{~mm}$ of rainfall during rainy season [5, 15, 38]. Due to high numbers of subsistence farmers depending on the yearly rainfall, this community is prone to seasonal fluctuations that create food shortages because they depend on a single staple harvest of corn and tubers after rainy season [37].

During the dry season, the farmers live off of the staple crops from the previous harvest until the rains come again so that they can harvest again and restock their depleted supplies [37]. The low diversity in staple crops (only corn and tubers) along with the increased desertification makes the population of Guiba highly susceptible to food insecurity. Dry season is characterized by the hot winds that blow from the Sahara desert and little or no rainfall. The highest recorded temperature in Burkina was $47^{\circ} \mathrm{C}$ and lowest temperature of $5^{\circ} \mathrm{C}$ [39]. The south has the largest rainfall and most moderate temperatures, this region is known as the most fertile region in Burkina Faso [39] although Guiba could be classified as a moderately fertile region since it is in the second highest rainfall zone [5, 15, 38, 39].

\section{Increasing desertification}

Burkina Faso faces recurring challenges that increase vulnerability and risks of food insecurity, including recurring droughts and locust invasions [3, 46, 49]. However, this has worsened in recent years with the Sahara desert edging into the country causing even greater water insecurity [8,9]. Of the three major rivers in the country (White Volta, Red Volta and Black Volta), only the Black Volta flows year round. There are often water shortages due to the water sources being present for only part of the year [15]. Guiba's ground water is easily accessible for three months of the year [5]. It has one manmade lake, which becomes completely dry during dry season [5]. This desiccation necessitates that villager's travel longer than normal distances in search of untapped water sources in 
nearby villages [personal observations]. Drought and climate change are heavily affecting the region's availability of water, pasture, and arable farmlands [15].

The increased desertification has been attributed to many human practices such as overgrazing of pastures, the slashing and burning of agricultural land, and over cutting of woodland for agriculture [8,9]. In Guiba these practices are common with only small corridors of trees left near water sources and the majority of the land cleared for agricultural practices [5]. The increase in these practices has contributed to the increasing desertification, which has a large impact on agricultural activities, population distribution and the economy [3]. The decreases in quality of all of these human indicators are known to correlate with a decrease in overall human health $[8,9]$. Most recently, malnutrition and dehydration killed thousands in the Middle East and northern Africa after a large heat wave $[37,55]$. Therefore, it is important to understand the variables that are connected to nutritional status so that proper methods can be used to tackle increased difficulties encountered with desertification.

\section{Food Availability and Consumption}

Increased food availability is a potentially important factor in decreasing the prevalence of chronic disease incidents in communities [26, 37, 54]. Food accessibility is determined by price and quality of food items [54]. A study of food markets located within different socioeconomic areas in the USA recorded a significant positive correlation of increased food accessibility with more nutritious food items purchased [54]. Dietary diversity scores (DDS) have been used to study the food consumed by individuals as a proxy for nutritional status [63]. Savy et. al 2006 found that women in Burkina Faso had lower DDS during the rainy months [37].

\section{Other Factors}

Dominguez-Salas et al. 2015 strengthened the findings in Savy et. al 2006 study showing that women had lower DDS during the rainy months ("hunger season," Figure 1), a season associated with decreased cereal intake and increased work intensity [26,59]. 
They found that these women also exhibited a lower body mass (BMI) [26, 59]. Savy et al. 2006 inferred that the lower BMI was a surrogate for nutritional status, therefore, the lower BMI during rainy season was due to decreased nutritional status in the women [26, 59]. However, Dominguez-Salas et al. 2015 found that, despite the decreasing BMI during hunger season, there were more epigenetic markers indicating an increase in nutritional status [59]. They associated this with increased consumption of green leafy vegetables that contained more nutrients than their usual cereal heavy diet which they ate during harvest time [59]. Therefore, these women were consuming a less diverse diet with higher nutritional value per food item versus high DDS diet lacking in micronutrients $[59,60]$.

\section{Malnutrition in children}

In sub-Saharan Africa malnutrition is a health burden that directly causes hundreds of thousands of deaths a year and indirectly causes half of deaths in children [26]. Malnutrition particularly affects children by impairing their immune system thereby increasing their susceptibility to disease $[26,37,56]$. In the preliminary results of the 2013 Burkina Faso standardized Monitoring and Assessment of relief and transitions (SMART) survey, $8.2 \%$ of children under five were suffering from moderate or severe malnutrition [46]. Thirty three percent of children less than five years old had stunted growth, and twenty six percent were estimated to be underweight despite the improvement in health over the past couple of years [49]. Micronutrient deficiencies are also high with eighty eight percent of children under five and forty nine percent of women suffering from anemia [46].

\section{Education and Gender Roles}

Malnutrition of children has also been associated with the education of family members; the education level of the mother has been closely related to her children's nutritional status and mortality [56]. Education and literacy continue to be a challenge in Burkina Faso with some of the lowest rates in the world [44]. Only $28.7 \%$ of the population over the age of 15 is able to read and write ( $36.7 \%$ of men and $21.6 \%$ of women) $[3,49]$. The 
school enrollment rate of males is higher $(65 \%)$ than the enrollment rate of females (52\%) [44]. In Burkina Faso boys receive preference in a family's decision to pay for schooling [1]. Gender inequality in the schools is conflated by the large dropout rate in Burkina Faso [19]. In 2011, only fifty two percent of children completed primary school and seventeen percent completed secondary school [49].

Another possible influence on nutritional status of schoolchildren is gender roles. In traditional Mossi society men are considered superior to woman [5]. The families follow paternal family structures and the power is passed down to the oldest son. Only men can control access to the land so for a female to access land she must be married [5]. Men are seen as the head of the family and are charged with earning money and family decisions. Women are charged with domestic tasks and seen as an integral part of the home [48]. The inequality of women's access to economic resources and lower social status increases likelihood of malnourishment, which has drastic impact on women's health (increased stunting, anemia, and diseases) as well as increased chance of having children who are born with low birth weights [58]. These gender roles also influence the order of food consumption and who gets the most nutritious part of the meal; for example a male in the family will eat first and will get the largest piece of chicken, if present, and most of the vegetables. The children will eat last and usually have a basic cereal with little or no meat and vegetables (personal observations).

\section{High disease prevalence}

Health of the schoolchildren could be influenced by factors other than dietary consumption; exposure to contaminated water and food pathogens could increase an individual's incidence of diarrhea. Diarrhea is the most common contributor of malnutrition by increasing breakdown of metabolic energy stored while simultaneously decreasing food intake and nutrient absorption [61]. Prevalence of diarrhea has been associated with bacterial and parasitic diseases that could be influenced by an individual's and family levels of education, individual and family hygienic practices, cultural customs, and socio-demographic information [26,36,37]. 
Eighty percent of diseases in Burkina Faso are caused by waterborne illnesses [9]. These waterborne diseases can be divided into three categories: vector pathogens (malaria, dengue, and yellow fever), food and waterborne pathogens (bacteria and amebas that lead to diarrhea), and water contact diseases (schistosomiasis) [3]. The highest causes of child deaths in Burkina Faso were from malaria (24\%), pneumonia (18\%), and diarrhea (12\%), with malnutrition linked to over thirty percent of all child deaths [49\}. Roughly seventy five percent of households in rural Burkina Faso have low access to improved water supplies contrasting the ninety five percent of households that have access in urban centers [8]. However improved sanitation facilities are less common with about fifty percent access in urban areas and only about seven percent access in rural communities which might be correlated with the very high risk of food, water borne, vector borne and respiratory diseases [3] thereby increasing the vectors of pollution of water sources due to unsanitary practices. It has been speculated that these problems are caused by pollution problems having to do with unregulated sewage dumped into bodies of water [9].

\section{RESEARCH}

\section{Research Background}

Living in Guiba, Burkina Faso provided me with a unique opportunity to experience the seasonality and food insecurity described in Figure 1. I was most interested in the nutritional status of the schoolchildren and used DDS as a proxy for nutritional adequacy. However, I hypothesized that seasonality was not the only possible variable that could be influencing the health of individuals living in the commune of Guiba. The commune was composed of different ethnic groups, individuals with drastically varying levels of education, and strong gender roles [personal observations]. I wondered about the effect on nutrition and health of these different variables within the commune and among the schoolchildren that I taught at Guiba's secondary school. I was also curious about the presence of fecal bacteria in the water sources near the secondary school because many schoolchildren complained of diarrhea and abdominal cramping. The following section explains the observations of Guiba that initiated my research questions and methods. 


\section{Ethnic Groups}

The commune of Guiba is composed of two principal ethnic groups. The Mossi and the Peuhls. The Mossi represent ninety percent of the total population found in the 21 villages of the Guiba commune and are known for stationary crops. The Peuhls are found among all the villages of Guiba but specifically in Kalenga, Parougri, and Ouétenga, where there is more pastoral land since they are known for migratory forms of food production [5 and personal observations].

Cultural practices related to food production among different ethnic groups and livelihood patterns can affect the infant mortality rate (IMR). A study performed in regions of moderate rainfall, like that of Guiba, found that there was increased IMR among individuals whose food production depended on stationary crops. Whereas, there was a decrease in IMR among individuals who practiced migratory forms of food production, such as herding and nomadic pastoralism $(5,6$, and 8) [38]. Interestingly, the Peuhls have very low enrollment rates of their children in school due to their nomadic lifestyle and previous studies show that lower education of households has been associated with poorer nutritional status [56].

\section{Research Development}

Living and teaching the schoolchildren in the commune of Guiba for 27 months provided an insight into the complexity of interacting environmental and social influences on illness associated with malnutrition. The prevalence of illness among the schoolchildren prompted me to explore the different possible influences of illness that exist within the commune of Guiba. As a volunteer teacher, I was most interested in what could be done to diminish the rates of illness within the commune.

The research development was influenced by the previous personal observations as well as by the two studies: Santos et al. 2007 and Muller Krawinkel 2005. Santos et al. 2007 provided a schematic diagram showing the connections of variations in climate on changing rates of child mortality. They attested that human health was controlled by 
environmental influences; for example the pervasiveness of pathogens were directly impacted by water quantity and quality. Some social determinants were accounted for in their study, however, the majority of the study focused on environmental influences on child mortality. Muller and Krawinkel 2005 took a larger approach. They argued that there are direct and indirect causes of malnutrition that can vary from drought and other environmental factors related to poverty and other social influences. The study in Guiba, Burkina Faso developed from a combined model of social and environmental influences on malnutrition.

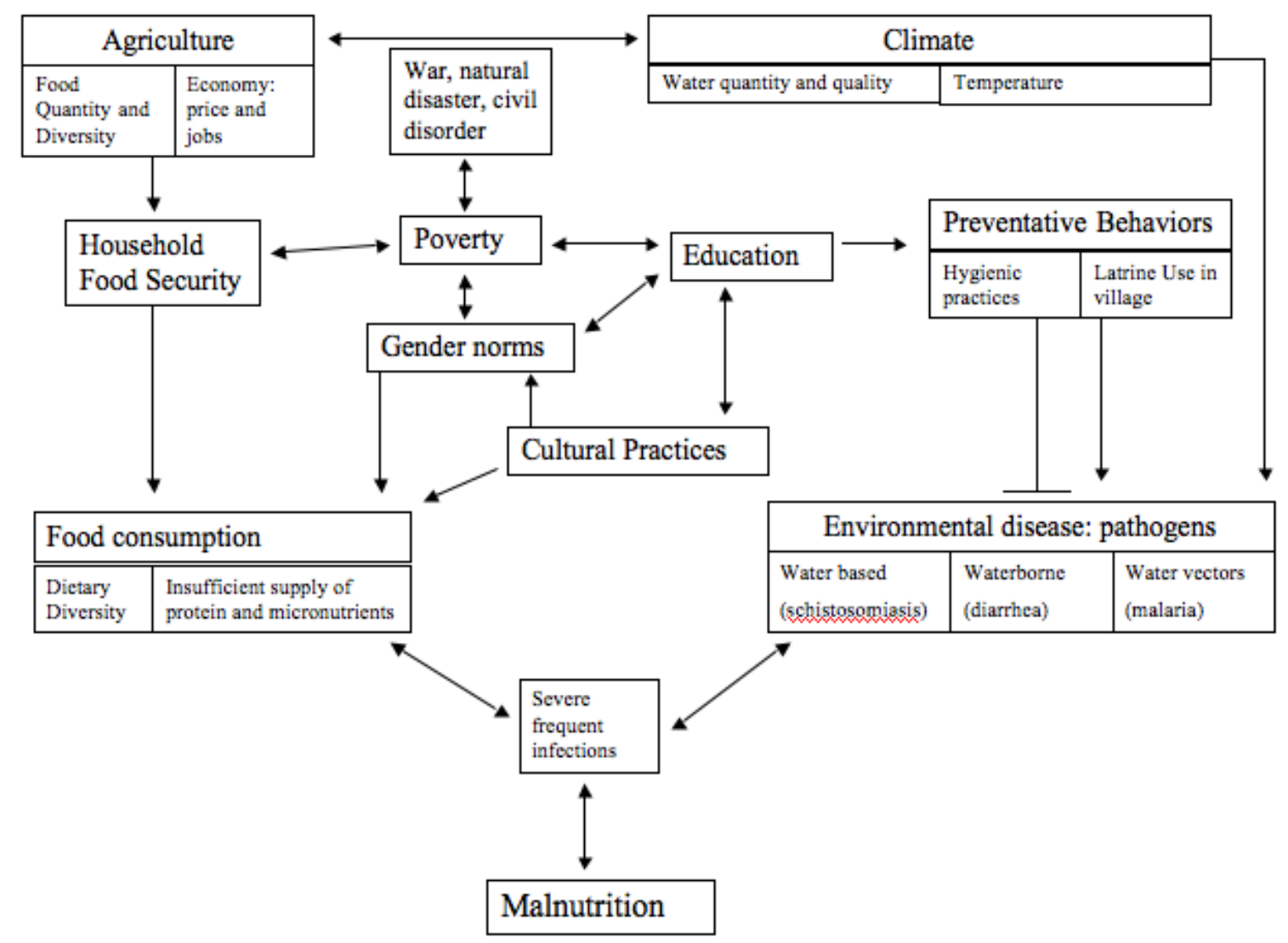

Figure 2. Potential Influencing Factors on Malnutrition. Arrows represent the direction of influence [adapted from 26 and 38]. 
Figure 2 visualizes the potential influences on malnutrition. For example, a desert climate will lead to less agricultural output thereby lowing the number of food items that are available to be consumed. Lowered dietary diversity has been associated with lower resistance to infection due to malnutrition [36]. The 27-month study examined environmental and social influences on malnutrition in order to understand possible positive interventions that could be used to work towards the alleviation of malnutrition in the commune of Guiba, Burkina Faso

\section{Study components}

A multi-component longitudinal study in Guiba was carried out from August 2013 to July 2015 to describe the prevalence of various factors in Figure 2. The first component measured food availability and accessibility at the main market in the commune of Guiba. To characterize the seasonality of food access in Guiba Burkina Faso, monthly market observations were documented throughout the two-year time period.

The second component examined food consumption. A survey was conducted in a single village at the end of the cereal 2014 shortage (October) and at the beginning of the cereal 2015 shortage (April). The two-stage sampling technique used in the study stemmed from the previous techniques applied in Savy et. al 2006. Three classrooms of schoolchildren were selected to participate in the survey. All of the adolescents attended the only secondary school in the commune of Guiba and were in the equivalent of U.S.A. $6^{\text {th }}$ and $7^{\text {th }}$ grades. These schoolchildren were surveyed in at the end of hunger season (October 2014) and the beginning of hunger season (April 2015). At the end of hunger season (October) the sample included 231 schoolchildren; 20 did not participate in the follow-up at the beginning of hunger season (April) due to refusal to take part in the study or because they ended the school year early due to pregnancy or other substantive circumstances. All of the schoolchildren gave their verbal consent to participate in the study and the headmaster of the school confirmed with written consent. 
The third component of the study explored other information that could influence nutritional status. A verbal quantitative study (Appendix B) characterizing sociodemographic, cultural, and sanitary information regarding the schoolchildren was conducted during the cereal shortage (May, 2015). The study was conducted with the same schoolchildren previously described along with the same verbal and written consent obtained.

The final component of the study examined water pathogens presence in drinking water sources. A qualitative study using petrifilm was conducted at the end of dry season (June 2015) and beginning of rainy season (July 2015). A total of 100 water samples were collected from ten different drinking sources located within a five-kilometer radius of Guiba's secondary school. The water samples were collected into $100 \mathrm{~mL}$ sterilized cups and then transferred to the $3 \mathrm{M}^{\mathrm{TM}}$ Petrifilm ${ }^{\mathrm{TM}}$ Count Plates using sterilized plastic pipettes

\section{Methods}

I collected data between the months of August 2013 and July 2015 since this was the time that I lived and worked in the Guiba commune. Other Peace Corps volunteers collected fragments of data measuring regional market variability with my oversight in their villages but none of the data was used in the results or conclusions since there was already a large amount of information collected from the Guiba commune.

\section{Food availability and accessibility}

The market observations were conducted by surveying individual markets following a detailed template to insure each market and each survey was conducted in the same manner. The food available for sale in each market was categorized based on quantity, quality, and price (Appendix A). The items present in market were recorded by their French common names and, if a word for the food item did not exist in French it was recorded in local language. Quantity of item in the market was defined as the number of women selling the food item. Quality was noted on a one to three scale. One was poor quality (mostly rotten, small, etc.) and three was the best quality. Price was noted when 
buying the food item or by asking the vendors. Price was recorded as price per quantity of item purchased. These surveys were conducted in the largest market within the commune of Guiba and repeated bi-monthly from August 2013 to July 2015.

\section{Food Consumption}

A two-series qualitative recall of all food items consumed by the schoolchildren during the previous 24-hour period was performed at the end and beginning of the cereal shortage (October 2014 and April 2015 respectively). Each student involved in the study was asked to write down all food items that were eaten the previous day including dishes, snacks, or other food. Students were then asked to identify the ingredients used to make the meals. All studies were performed during weekdays due to the fact that the students were in class. Analysis of days aligning with local holidays, feasts, and celebrations were not included in the study. A single interviewer with a university education conducted the study in French since it is the official spoken language of secondary education in Burkina Faso.

\section{Other Information}

Socio-demographic, cultural, and sanitary information were gathered using a detailed cultural survey (Appendix B) that was distributed to 231 school children that attended the only secondary school in the commune of Guiba. The survey was distributed every month during the 2014 to 2015 school year. Analyses were conducted at the end of cereal 2014 shortage (October) and at the beginning of the cereal 2015 shortage (April) since these are the months with the largest variation in cereal presence. In October, the sample included 231 schoolchildren; 20 did not participate in the follow-up in April due to refusal to take part in the study or because they ended the school year early due to pregnancy or other substantive circumstances. A hygiene index was formed to provide information about hygiene practices at a compound level. The index was constructed from information on latrine use, hand washing practices and food sanitation practices. Each positive practice was given a count and these counts were divided into terciles to create three levels of hygienic conditions: high, medium, and low. Bi-variant variables 
such as village access to infrastructural amenities (running water and electricity), as well as, education levels of direct family members were categorized. Socio-demographic and cultural determinants were also grouped based on terciles or as bi-variants.

\section{Water pathogens}

A qualitative study using petrifilm was conducted at the end of dry 2015 season (June) and beginning of rainy 2015 season (July) to understand the difference in water contamination between the two seasons. A total of 100 water samples were collected from ten different drinking sources located within a five-kilometer radius of Guiba's secondary school. The water samples were collected into $100 \mathrm{~mL}$ sterilized cups and then transferred to the $3 \mathrm{M}^{\mathrm{TM}}$ Petrifilm ${ }^{\mathrm{TM}}$ Count Plates using sterilized plastic pipettes; the transfer of water to the plate was the inoculation step. A plate was inoculated by lifting the top of the film and adding a sample of water to the center of the plate. After inoculation, the film was placed over the water sample and flattened with an evenly distributed pressure to prevent contamination of the sample. The sample was allowed to incubate at air temperature for 24-48 hours. After incubation, the $3 \mathrm{M}^{\mathrm{TM}}$ PetrifilmTM EC plates results were interpreted. A count of colonies was performed; all red colonies with associated gas bubbles were counted as coliform and blue colonies with associated gas bubbles were counted as E. coli. The total numbers of fecal colonies were determined by adding the two blue and red colonies together. The count of fecal colonies was then compared across the ten drinking sources to examine the relative presence of waterborne pathogens in drinking water near the secondary school. According to the WHO guidelines, unsafe drinking water is characterized by a single coliform or E. coli present in the $100 \mathrm{ml}$ sample [62]. Therefore, any water sources with the presence of a single E. coli or coliform were classified as contaminated.

\section{Data Management and Analysis}

Data entry and analysis were performed with Microsoft Excel software, version 11.6.6. The entry and reentry of data ensured the quality of the data. 


\section{Food availability and accessibility}

Between August 2013 and June 2015, bi-monthly market surveys recording the variation in the numbers of vendors selling specific food items at market were conducted in the commune of Guiba. The month of July was excluded from the study sample since I was ill during this time period. The number of market vendors selling certain food items served as a proxy for availability of food items in market. Each food item that was recorded was also recorded with the price per item or bulk of items in order to analyze the accessibility of the food item. The two collected data points, from the beginning and end of the month, were averaged to get a general idea of availability for a specific food item for the whole month being analyzed. These food items were then placed in their food groups using the same grouping technique described with DDS to better compare the presence of certain food groups based on seasonality. Market observations were analyzed using the number of vendors selling specific food groups and comparing across the two-year time period using time as the independent variable and frequency of food group present as the dependent variable. In addition, error was determined using the variation of all the items with in the food group across the two year time period.

\section{Nutritional Value of Food items in market}

To understand the nutritional value of food items in market the FAO West African Food Composition Table was simplified [64, 65]. The individual food items were classified into food groups. Grouping by food groups allows for the calculation of dietary diversity score. Dietary diversity scores were used as proxies for macro and micronutrient adequacy of the diet for the schoolchildren who attend secondary school in the commune of Guiba $[11,24,35,36,64,65]$. Table 1 shows the food items classified in each food group as well as the nutritional value associated with each food group. Soumbala and peanuts are high in calories, protein, and a source of several types of dietary fibers and minerals including B vitamin, vitamin E, dietary fiber, phosphorus, and magnesium. Mangoes, eggplant, and green leafy vegetables (barbenda leaves) are rich in vitamin A [64]. 
Table 1. Food items classified by food groups and the nutritional value associated with each food group [64].

\begin{tabular}{|c|c|c|}
\hline Food group & Examples of food items & Nutritional Value \\
\hline Cereals & $\begin{array}{l}\text { corn, rice, millet, sorghum, } \\
\text { noodles, porridge, couscous }\end{array}$ & energy source \\
\hline $\begin{array}{l}\text { Green leafy } \\
\text { vegetables }\end{array}$ & $\begin{array}{c}\text { leafy vegetables including } \\
\text { wild forms such as barbenda } \\
\text { and baobab leaves }\end{array}$ & $\begin{array}{c}\text { source of vitamins such } \\
\text { as vitamin A }\end{array}$ \\
\hline Other Vegetables & $\begin{array}{l}\text { tomatoes, onions, eggplant, } \\
\text { okra, and peppers }\end{array}$ & vitamin source \\
\hline Roots/Tubers & $\begin{array}{c}\text { potatoes, yams, cassava, } \\
\text { carrots, squash, sweet } \\
\text { potatoes }\end{array}$ & energy source \\
\hline Fruit & $\begin{array}{l}\text { mangoes, guava, papaya, fruit } \\
\text { juice, and wild fruits }\end{array}$ & $\begin{array}{c}\text { source of vitamins such } \\
\text { as vitamin A }\end{array}$ \\
\hline Pulses and nuts & $\begin{array}{l}\text { beans, peas, nuts, seeds, and } \\
\text { foods made from these such } \\
\text { as peanut butter and oils }\end{array}$ & $\begin{array}{l}\text { protein, vitamins, and } \\
\text { energy source }\end{array}$ \\
\hline Meat/poultry & $\begin{array}{l}\text { pork, beef, goat, lamb, } \\
\text { chicken, game animals, birds, } \\
\text { lizards, rats/mice, and insects }\end{array}$ & protein source \\
\hline Fish/sea food & fresh or dried fish & protein source \\
\hline $\begin{array}{l}\text { Milk/dairy } \\
\text { products }\end{array}$ & milk, yogurt, dried milk & protein and vitamin $\mathrm{C}$ \\
\hline Sugars & $\begin{array}{l}\text { sugar, honey, soda, juice, } \\
\text { chocolates, candy, cookies }\end{array}$ & energy source \\
\hline Oils/fats & oil, fat, and butter & energy source \\
\hline Condiments & spices and buyon cubes & possible vitamin source \\
\hline
\end{tabular}




\section{Food Consumption}

Individual dietary diversity scores (DDS) of adolescents were found using a dietary diversity survey. DDS served as a proxy and reflection of nutritional adequacy in the schoolchildren who attended the secondary school in the commune of Guiba. The DDS were conducted in French with three different classrooms at the secondary school in the commune of Guiba. Respondents were given a random number for identification of the anonymous responses. The surveys were conducted monthly during the 2014 (October) to 2015 (May) school year. The questionnaires used in the DDS survey followed a specific template that asked about food intake during the morning, afternoon, evening and snacks (Appendix E).

The technique for calculating DDS closely followed those described in previous studies $[11,24,35,36,63]$. First each food item was given the score of 0 if not present in market or 1 if present. Then the food items were categorized into one of the thirteen food groups present in West Africa. The scores in each food group were summed for each individual to give the DDS score for the individual. Then these scores were divided into terciles allowing for the classification of high, medium, and low DDS.

\section{Other Information}

To understand the social composition of the study population the cultural, sociodemographic, and socioeconomic information was analyzed using two methods. The first method examined variables that had only two possible outcomes such as presence of electricity. These outcomes were then divided by the total number of possible outcomes in the population to find the percentage of the population in the category. To find the percentage of schoolchildren within the survey population that fall under one of the two outcomes, the last calculated number was multiplied by one hundred. The second method looked at variables with a range of outcomes such as age. These variables were averaged to give the mean and then the standard deviation was found to determine the error within the variables. Finally, these numbers were compared against the low, medium and high DDS to give the percentage of each category with certain characteristics. For example, 
since $34.6 \%$ of schoolchildren have access to electricity in their village the percentage of that subpopulation had low, medium, and high DDS was analyzed.

\section{Water pathogens}

The presence of water pathogens in ten water sources near the secondary school in the commune of Guiba was collected to quantify the contamination level of water sources near the school that the majority of schoolchildren drink from during the school year [personal observations]. The water sources contamination levels were analyzed after the samples were collected and allowed to incubate. Following the incubation of the 100 petrifilm samples the count of fecal coliform and E.coli was determined by recording the number of red colonies with associated gas bubbles (coliform) and blue colonies with associated gas bubbles (E. coli). The total presence of fecal bacteria (coliform and E.coli) was found by adding the number of E.coli found with the number of colifom. Drinking water is unsafe if there is a single coliform or E. coli present in $100 \mathrm{ml}$ sample according to the World Health Organization (WHO) standards. The presence of a single fecal bacterium on a petrifilm classified the water source as contaminated [62]. After analysis of the samples, the water sources were separated into two categories: not contaminated and contaminated with fecal bacteria. Those water sources contaminated with fecal bacteria were further ranked comparing the counts of fecal bacteria between samples. These results were then tabulated to examine the water sources' distance from the school ground and total presence of fecal bacteria.

\section{RESULTS}

Socio-demographic characteristics of the sample (Table 2)

The sample included 211 households comprising of 3 to 22 individuals per household (mean $8.2 \pm 3.7$ individuals per household) living in homes with less rooms than people on average (mean $5.6 \pm 2.5$ rooms). The mean age of the person surveyed was $16 \pm 1.5$ with a range between 12 to 20 years old. All of the respondents to the surveys were schoolchildren who attended secondary school in the commune of Guiba. Every student spoke at an elementary level of French and exhibited basic French writing skills so that 
they were able to respond to the verbal surveys. The majority of the individuals in the sample belonged to the Mossi ethnic group (98.5\%) with the other groups being Gouronsi and Bissa (1.5\%). No Peuhl children were found in the surveyed population because formal education does not align with a nomadic lifestyle [personal observations]. The sample group was almost evenly split with respect to religion (49.5\% Muslims, 50.5\% Christians), and gender (males 46.7\% and females 53.3\%). More than half of the heads of household never attended school (62.3\%) and an even larger percentage do not speak French $(64.6 \%)$. The number of mothers with no schooling was slightly higher than their male counterparts $(67 \%)$. The majority of heads of households work in agriculture $(87.3 \%)$. Gender roles were consistent in the sample with all of the individuals stating only women cooked (100\%) and a majority of the individuals saying that males should get the largest piece of chicken (91\%).

Table 2. Percentage of individuals among schoolchildren informants within each socio-demographic criteria. Heads of household are only male. French level was consider yes if speak any amount. Secondary activities were classified as those other then farming.

\begin{tabular}{lr}
\hline Statistic unit=adolecents & $\%(\mathrm{n}=211)$ \\
\hline \hline Age & \\
$<15$ years & 11.4 \\
15-17 years & 71.1 \\
18 years or more & 17.5 \\
Ethnic Group & \\
Mossi & 98.5 \\
Gurunsi & 1.0 \\
Bissa & 0.5 \\
Religion & 49.5 \\
Muslim & 50.5 \\
Christian & \\
View Malnutrition as Problem in their Village & 91.9 \\
Yes & 8.1 \\
No & \\
Education of head of household & 37.7 \\
Educated & 62.3 \\
Uneducated & \\
Education of Mother &
\end{tabular}


Educated

33.0

Uneducated

67.0

French Level of head of household

Yes

35.4

No

64.6

Secondary activity of head of household

Yes

12.7

No

87.3

Women Cooking

Yes

100

No

Father or Grandfather get biggest piece of

chicken

Yes

91.0

No

9.0

Size in number of households

One to Two

2.8

Three to Four

88.2

Five and more

9.0

Size in number of rooms

Three or Less

18.5

Four to Six

52.6

More than Seven

28.9

Size in number of individuals

Less than or equal to five

20.3

Six to Twelve

72.2

Greater than Twelve

7.5

Hygiene Index

Low

30.3

Medium

63.5

High

6.2

Access to Running Water

Yes

6.2

No

93.8

Access to Electricity

Yes

34.6

No

65.4 


\section{Living conditions of the schoolchildren}

Guiba is a commune composed of 21 different villages. Each village has many compounds; compounds are grouped clusters of households that represent extensive and large family units. Each compound is composed of multiple households. Households are individual living structures within a compound (Figure 3).

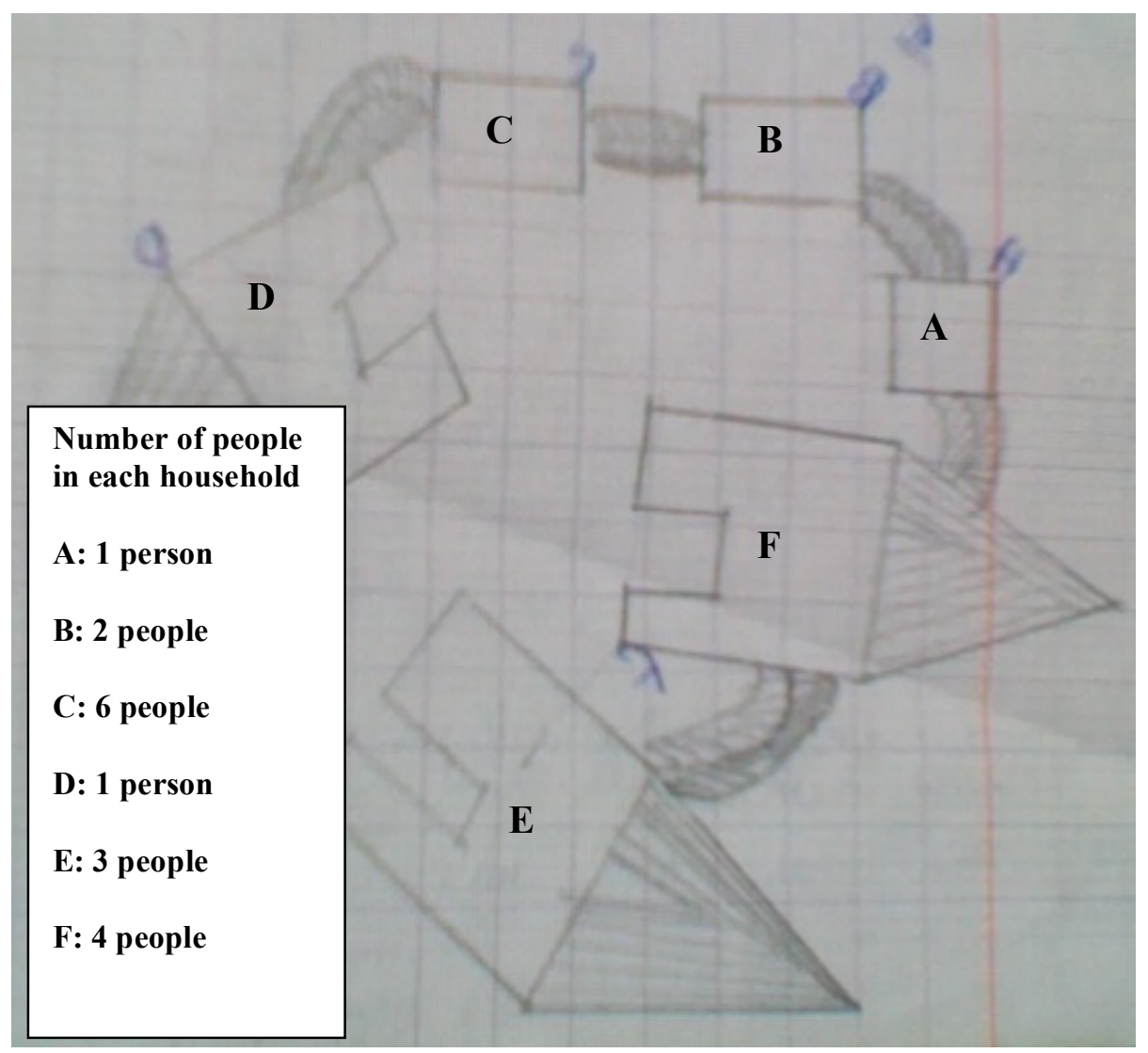

Figure 3. Example of an individual schoolchild's response and drawing of their compound. The compound structures are labeled A to E. The households are each individual structure alone.

The majority of schoolchildren in villages within the commune of Guiba live without electricity (65.6\%) and an even larger percentage live within compounds without electricity (93.4\%). There is no running water in the villages in the commune of Guiba. Five of the eight individuals who lived outside the commune of Guiba in Manga, Bobo, or Ouagadougou had running water (62.5\%) and all had electricity in their compounds. During the school year, a large proportion of households drank water from the pumps in 
Guiba (83.5\%), a few drank water from a well (8\%), a limited number of households drank water from the man-made lake $(0.5 \%)$, and a handful of schoolchildren who lived outside of the commune drank water from a tap ( $8 \%)$.

\section{Availability of Nutritious Food (Table 1)}

The availability of food in the market ranged greatly over the twenty-two months period investigated from 2013 to 2015. During this period, the number of vendors present in market ranged from 17 to 72 (Figure 4).

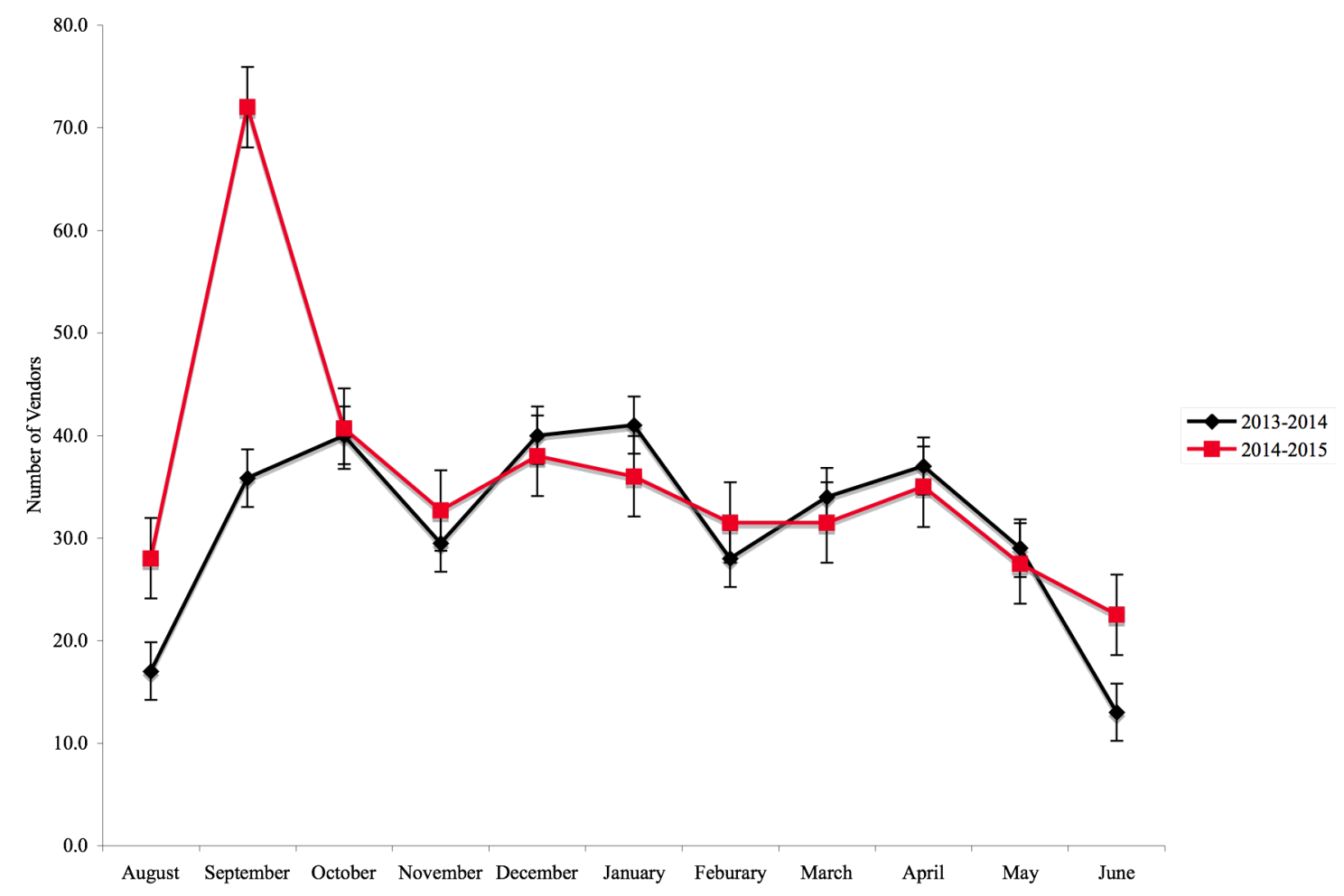

Figure 4. Number of food vendors in the market each month for the periods of 2013-2014 and 2014-2015.

Harvest season ranges from the end of September to December in Guiba depending on the previous years rainfall and planting season (Figure 1). The largest number of vendors was observed at the beginning of the harvest season 2014 (72 vendors September) and 2013 (40 vendors October) (Figure 1 and Figure 4). Twenty-six different vendors were selling three different types of vegetables $(6 \pm 0.1$ tomatoes vendors, $8 \pm 2$ African 
eggplant vendors, $5 \pm 2.5$ American eggplant vendors, and $7 \pm 2.8$ okra vendors) that are vitamin sources beginning of an average harvest season.

At the beginning of hunger season there were not as many vendors in market $(36 \pm 1.4$ vendors in April) compared to the end of hunger season (40 \pm 0.5 in October). The beginning of an average hunger season was characterized by an increase in food sources rich in vitamin A especially mangoes $(10 \pm 2$ vendors) and barbenda leaves $(4 \pm 0.7$ vendors) with nine vendors selling one source of protein ( $9 \pm 2.1$ soumbala vendors). During the end of hunger season, eleven vendors were selling two sources of protein $(6 \pm$ 3.4 peanuts vendors, and $5 \pm 1.2$ soumbala vendors) and nine vendors were selling two vitamin sources ( $5 \pm 0.4$ chives vendors and $4 \pm 1.3$ African eggplant vendors).

The lowest number of vendors was at the start of planting (June) during the middle of hunger season (Figure 1 and Figure 4). During an average hunger season (June), four vendors were selling two sources of protein $(2 \pm 1$ soumbala vendors and $2 \pm 1.8$ peanut vendors) and six vendors were selling two sources of vitamin A (3 \pm 1.4 barbenda vendors and $3 \pm 0.7$ mango vendors).

Figure 4 was further deconstructed into the food groups each vendor was selling in order to characterize the presence of certain food groups throughout the twenty-two month observation period. These food groups included: 1) roots, tubers, and nuts, 2) other vegetables (onions, corn, okra, peppers, squash, carrots, eggplant, and cucumbers), 3) fruits, and 4) green leafy vegetables (Figure 5, 6, 7, and 8). Sugars, fats, meats, bread and dairy products were not graphed due to the low presence of vendors at the Guiba market over the observation period. Eggs were not graphed because of a strong cultural conviction that children should not consume eggs and none of the schoolchildren reported eating eggs; I was told that it is believed that children who consume eggs will become thieves (personal observations). 
The lowest numbers of vendors, in three out of the four food groups (roots and tubers, other vegetables, and fruits), were found in the middle of hunger season (June and August). Roots and tubers, a prime energy source, were relatively rare during the three months in the middle of hunger season (mean $=12.5 \pm 2.9$ vendors from September to May) (Figure 5).

\section{Roots and Tubers}

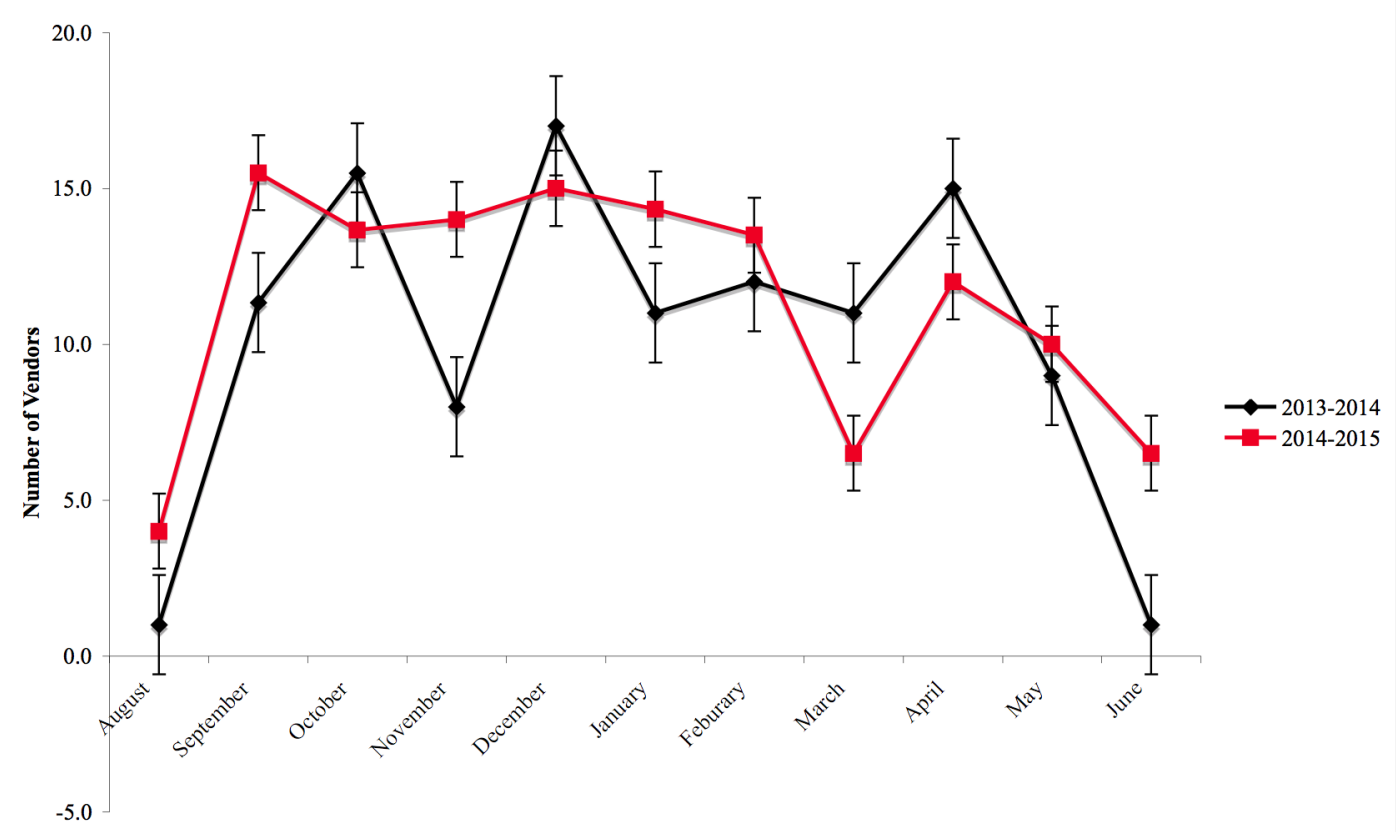

Figure 5. Number of vendors selling roots, tubers, and nuts each month for the periods 2013-2014 and 2014-2015.

Other vegetables, a good source of vitamins, were also least common during the middle of hunger season. There was a spike in vendors selling other vegetables at the beginning of harvest season (September) and the month just after garden season (March) (Figure 6).

The lowest numbers of fruit vendors were found during the middle of hunger season. No fruit was sold during the month with the highest amount of rain (August) (Figure 7). There was a spike in vendors selling fruit at the beginning of hunger season during a time known as "mango season" because of the high prevalence of mangoes (personal observations). Mangos are known to be a good source of vitamin A [64]. 


\section{Other Vegetables}

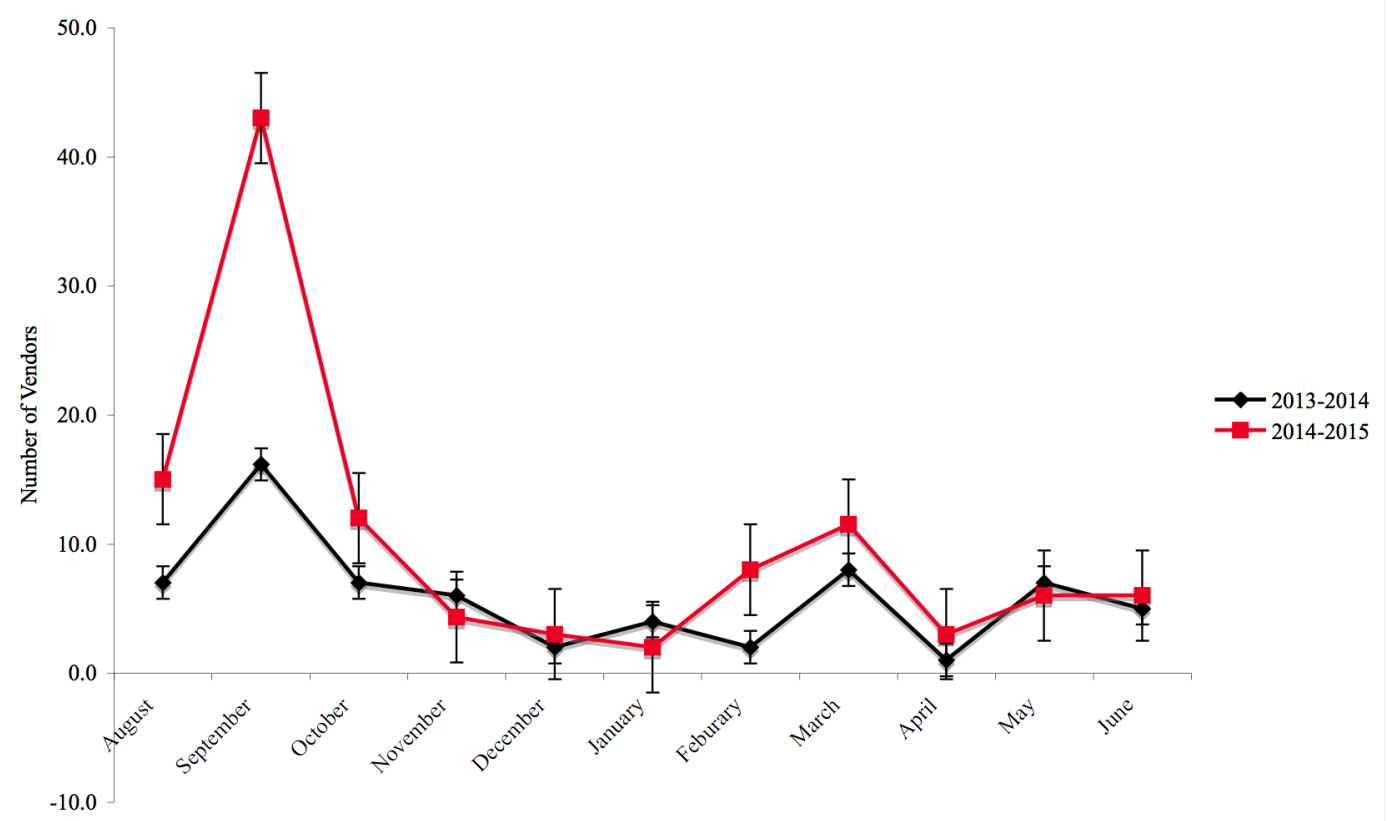

Figure 6. Number of vendors selling other vegetables each month for the periods 2013-2014 and 20142015.

\section{Fruit}

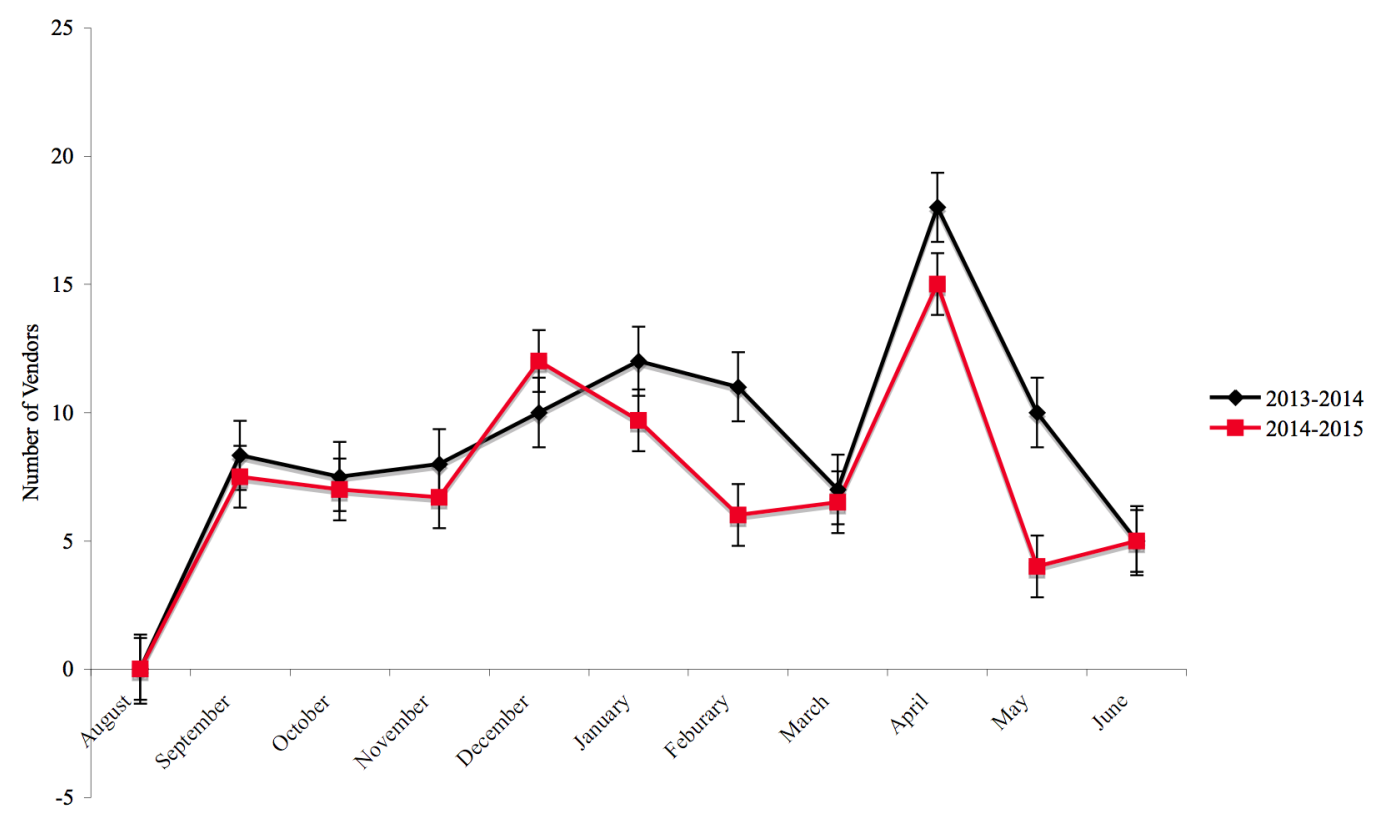

Figure 7. Number of vendors selling fruits each month for the periods of 2013-2014 and 2014-2015. 


\section{Green Leafy Vegetables}

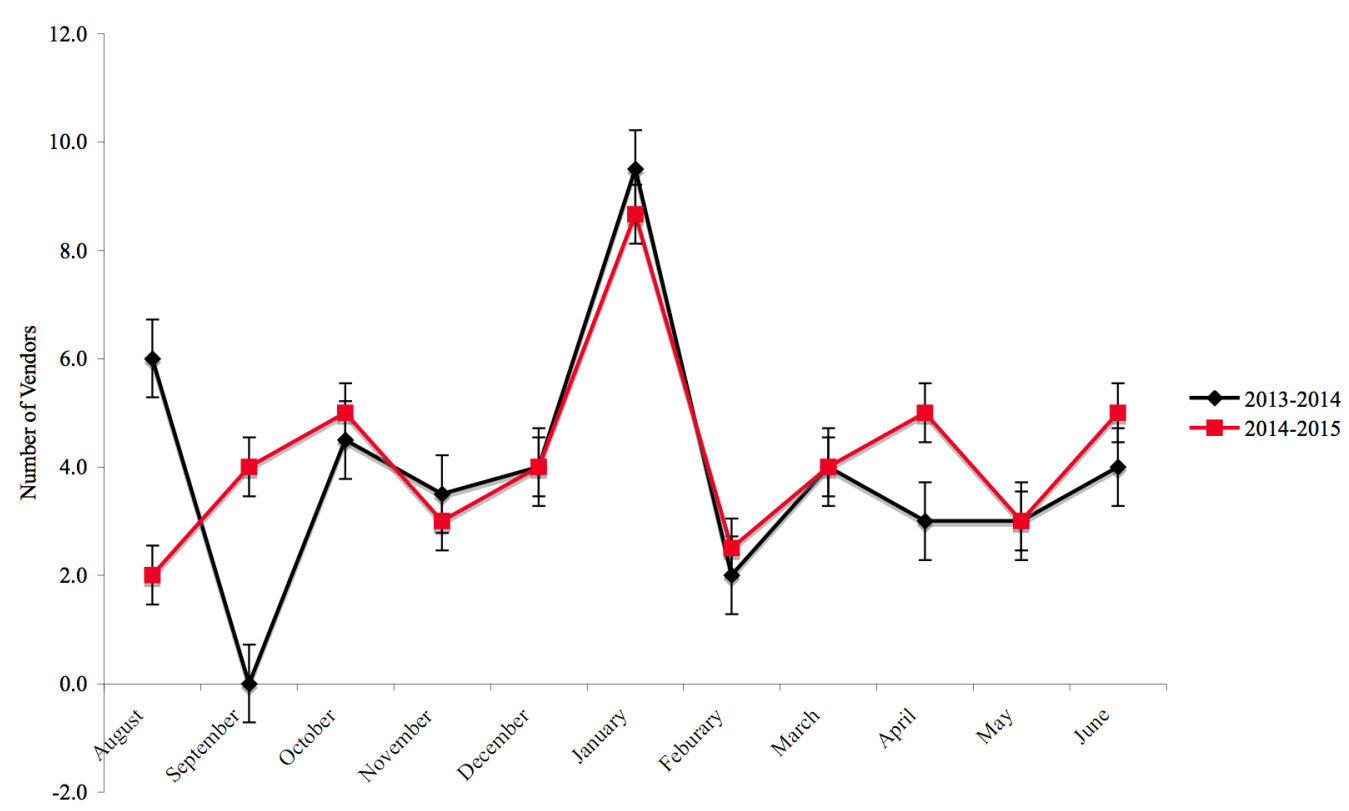

Figure 8. Number of vendors selling green leafy vegetables each month for the periods 2013-2014 and 2014-2015.

Green leafy vegetables, high in beta-carotene and vitamin A, had an increase of vendors present in market during the middle of hunger season and around the time of planting (June, Figure 1 and Figure 8). The spike of green leafy vegetables seen in garden season (January) is caused by the presence of chives in market, which are not as nutritious as leaves that were found in the middle of hunger season [64].

\section{Frequency of Dietary Diversity (Figure 9)}

FAO/WHO have commonly identified 116 locally cultivated food items present in Burkina Faso [36, 37], however, only 30 food items were reported on the DDS qualitative survey; the 30 identified food items were categorized into 14 possible food groups. The range of DDS scores varied by month; April DDS ranged from 2 to 11 and October DDS ranged from 1 to 10 (Figure 9). Of note, the October DDS has a relatively even bell curve when analyzing the distribution of frequency to DDS whereas the April DDS shows an 
abrupt jump in frequency at a DDS of 8 that increases to a max at 7 DDS and then drops off (Figure 9).
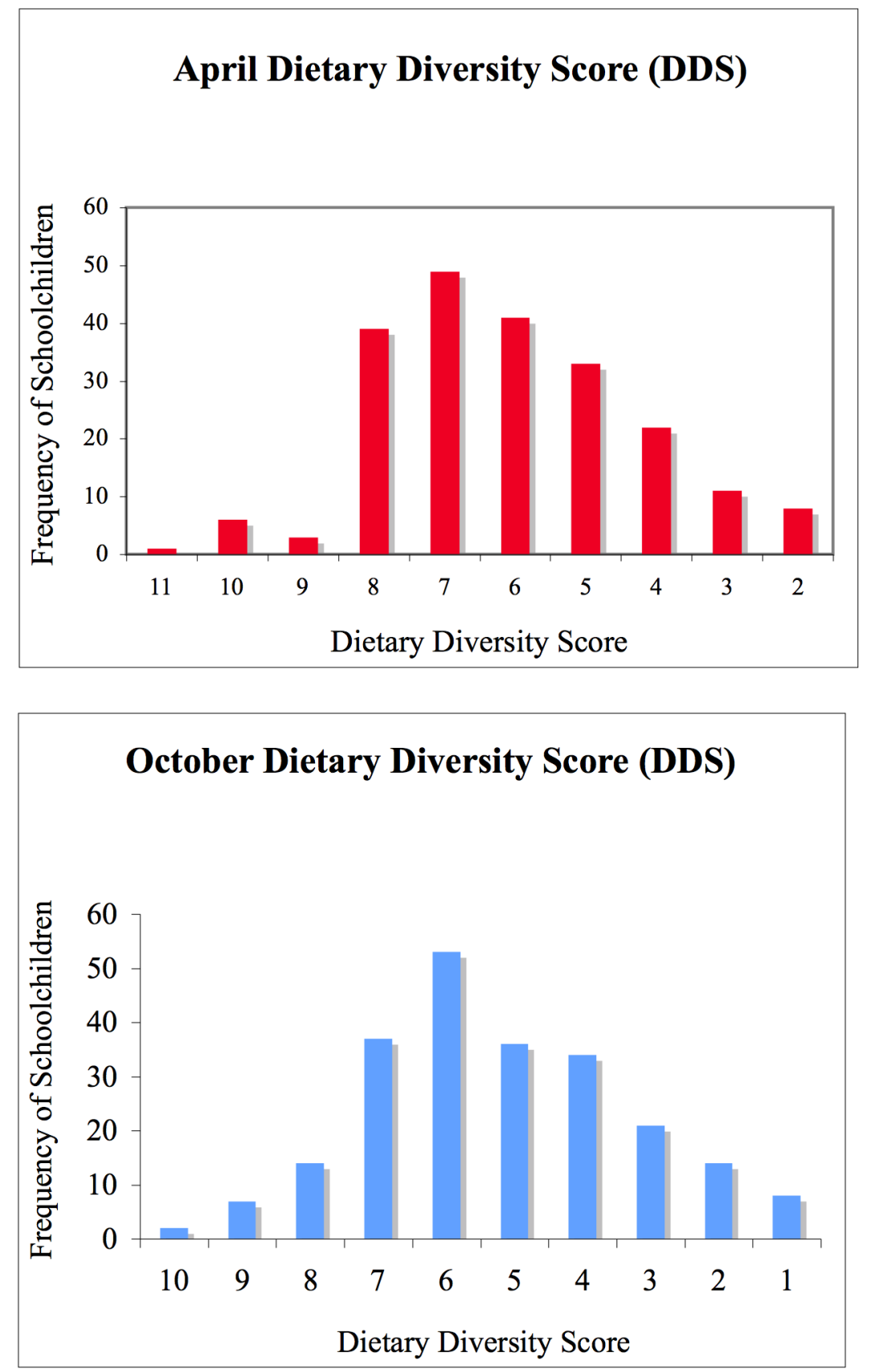

Figure 9. Frequency of schoolchildren with different dietary diversity scores at the end of 2014 hunger season (October) and the beginning of 2015 hunger season (April). 


\section{Dietary Diversity Scores (Figure 10 and 11)}

The staple meal year-round is tô. Tô is a dough-based meal of cooked cereal (mostly corn or millet) and has minimal nutritional value [64]. The common sauce eaten with tô consists mainly of other vegetables (tomatoes $21 \%$ ), condiments (19.2\%), and oils/fats $(7.5 \%)$.

Few schoolchildren reported consumption of roots and tubers, a source of energy, at the start or end of hunger season ( $0 \%$ October, $0.1 \%$ April); only a small number of high DDS individuals reported consumption of roots and tubers during the same time period.

Some schoolchildren also consumed fruit and fish; more fruit and fish were consumed at the beginning of hunger season (April fruit 5.35\% and fish 6.7\%) than the end of hunger season (October fruit $0 \%$, fish 3.8\%). At the beginning of hunger season (April), fruit consumption was reported by all DDS (low, medium, and high). No schoolchildren reported consuming fruit at the end of hunger season; consequently, the lack of consumption of fruit means that schoolchildren are missing a prime source of vitamin A $[64,65]$. Therefore, there were more vitamins and protein sources consumed by schoolchildren at the beginning of hunger season than at the end of hunger season.

Low DDS schoolchildren did not consume meat/poultry. Schoolchildren with low scores had very simple diets year-round largely consisting of cereal and, about half, reported consumption of other vegetables and condiments. A few schoolchildren with low DDS reported drinking milk or other dairy products (3.4\% April and 9.7\% October). No schoolchildren with low DDS reported eating roots/tubers. 


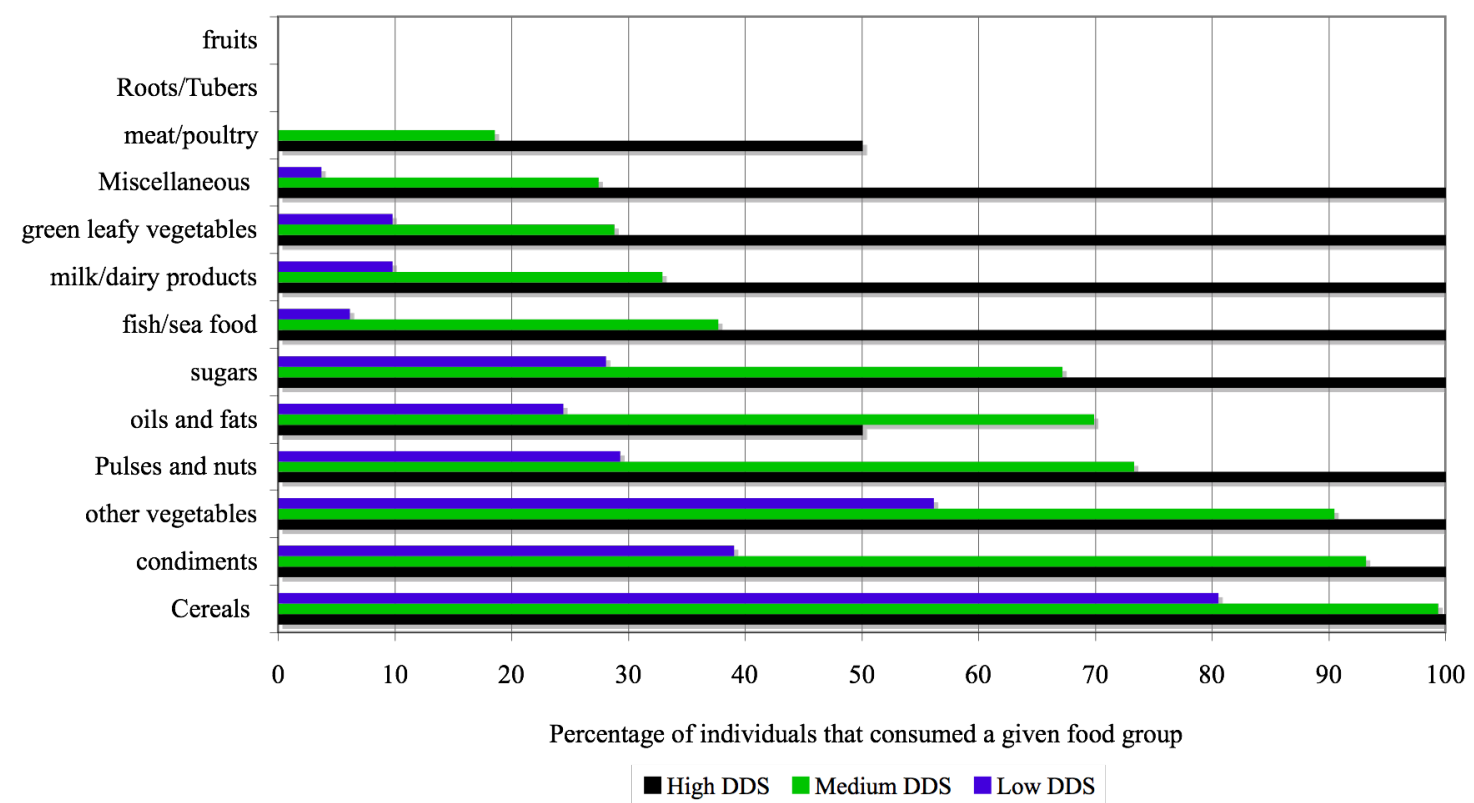

Figure 10. Percentage of low, medium, and high DDS classified by food group at the end of hunger season (October 2014).

A larger percentage of schoolchildren with medium scores consumed cereal, vegetables, and condiments compared to individuals with low DDS. Individuals with medium DDS had more energy and protein in their diet than schoolchildren with low DDS (medium DDS reported consumption of pulses, oils/fats, and fish). However, few schoolchildren with medium DDS reported consumption of meat/poultry (5.5\% April and $18.4 \%$ October).

All individuals with high diversity scores ate cereals, condiments, other vegetables, pulses and nuts, oils and fats, miscellaneous items, and fruits. These individuals also ate a large number of fish, sugar, green leafy vegetables and dairy products. Most individuals with high DDS were consuming meat/poultry (28.5\% April and 50\% October) and oils/fats (100\% April and 50\% October). 
Percentage of each food group consumed by schoolchildren with different DDS in April

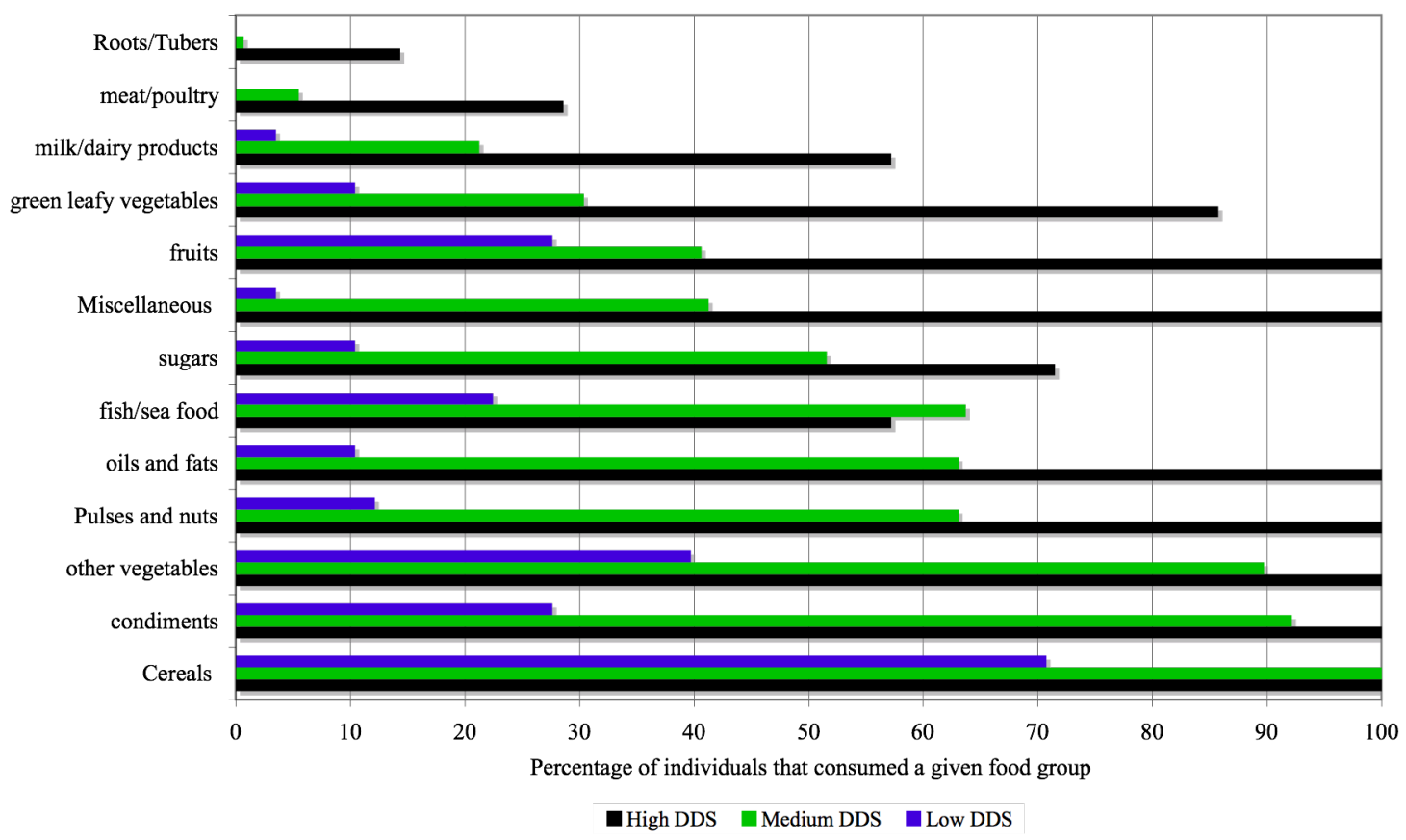

Figure 11. Percentage of low, medium, and high DDS classified by food group at the beginning of hunger season (April 2015).

Dietary Diversity and Socio-demographic Indicators (Table 3)

The following section examines the DDS relation to different socio-demographic indicators of health. The majority of respondents had medium DDS across all sociodemographic categories.

DDS could be related to the number of households composing a compound. Small compounds (only one to two households) did not exhibit high DDS at the end of hunger season $(0 \%$ of individuals in October). As the number of rooms in a household increased less individuals from that group exhibited a high DDS at the end of hunger season. Therefore, it is better to have more households with fewer rooms if an individual wants to maintain high nutritional DDS. This finding may be associated with more bartering power involved in having more households and fewer mouths to feed in each individual household. 
The number of individuals living in a compound could be related to DDS at the end of hunger season (October). Few schoolchildren $(\sim 8 \%)$, at the end of hunger season, reported high DDS if they lived in compounds with less than twelve people. Therefore, a larger number of individuals living together maybe associated with high DDS at the end of hunger season.

Better access to infrastructure (running water and electricity) seems to be associated with higher DDS. Most schoolchildren with access to electricity reported medium or high DDS (92.3\%). Schoolchildren with access to running water also had mostly medium or high DDS (61.5\% and $15.9 \%$ respectively).

Schoolchildren with an educated mother reported high DDS (15.9\%) more often than schoolchildren with uneducated mothers (6.4\%). Education of a schoolchild's father, as shown in previous papers, had little relation to the DDS [56]. Thus, education of a schoolchild's mother might be associated with higher schoolchildren DDS. Lower educated mothers and children will have fewer chances to learn about importance of difference preventative behaviors in decreasing exposure to environmental pathogens (personal observations). These families do not use the latrines as often and contaminate the nearby food and water sources $(22.3 \%$ children reported using the latrine). After being contaminated, these water sources are consumed by the families who get ill and continue to contaminate their living spaces in vicious cycle [26].

There was also a relation between age and DDS. No younger children (less than 15 years old) reported high DDS at the end of hunger season. Younger children reported that they were last to eat more often than the older children $(68 \%)$, therefore, they usually consumed higher amounts of cereal and less vitamin and protein sources.

Religion has a complex association with DDS. Few Muslims reported high DDS (8.7\%) compared to Christians (35.1\%). However, the majority of Christians reported low DDS 
(64.9\%). No Christians reporting medium DDS and the largest proportion of Muslim individuals had medium DDS (60.0\%).

Table 3. DDS by Month compared to Socio-demographic characteristics of individuals

\begin{tabular}{|c|c|c|c|c|c|c|}
\hline & & tober DDS ( & & & ril DDS $\left({ }^{0}\right.$ & \\
\hline & Low & Medium & High & Low & Medium & High \\
\hline $\begin{array}{l}\text { Size in number of } \\
\text { households }\end{array}$ & & & & & & \\
\hline One to Two & 45.5 & 54.8 & 0 & 19.4 & 51.6 & 29 \\
\hline Three to Four & 33.8 & 54.8 & 11.5 & 24.7 & 53.2 & 22.1 \\
\hline Five and more & 31.6 & 57.9 & 10.5 & 28.6 & 61.9 & 9.5 \\
\hline Size in number of rooms & & & & & & \\
\hline Three or Less & 23.1 & 66.7 & 10.3 & 30.8 & 46.2 & 23.1 \\
\hline Four to Six & 36.0 & 57.7 & 6.3 & 23.4 & 55.0 & 21.6 \\
\hline Seven and more & 42.6 & 42.6 & 14.8 & 21.3 & 57.4 & 21.3 \\
\hline $\begin{array}{c}\text { Size in number of } \\
\text { individuals }\end{array}$ & & & & & & \\
\hline $\begin{array}{l}\text { Less than or equal to } \\
\text { five }\end{array}$ & 37.8 & 53.3 & 8.9 & 31.1 & 42.2 & 26.7 \\
\hline Six to Twelve & 38.5 & 53.2 & 8.3 & 27.0 & 55.0 & 18.0 \\
\hline Greater than Twelve & 45.7 & 37.1 & 17.1 & 20.0 & 60.0 & 20.0 \\
\hline Hygiene Index & & & & & & \\
\hline Low & 39.1 & 53.1 & 7.8 & 14.1 & 64.1 & 21.9 \\
\hline Medium & 45.8 & 45.8 & 8.3 & 28.4 & 49.3 & 22.4 \\
\hline High & 38.5 & 53.8 & 7.7 & 23.1 & 61.5 & 15.4 \\
\hline $\begin{array}{l}\text { Education of head of } \\
\text { household }\end{array}$ & & & & & & \\
\hline
\end{tabular}




\begin{tabular}{|c|c|c|c|c|c|c|}
\hline Educated & 26.6 & 63.3 & 10.1 & 20.6 & 34.3 & 45.1 \\
\hline Uneducated & 39.4 & 51.5 & 9.1 & 22.0 & 60.6 & 17.4 \\
\hline \multicolumn{7}{|l|}{ Education of Mother } \\
\hline Educated & 30.4 & 53.6 & 15.9 & 20.3 & 50.7 & 29.0 \\
\hline Uneducated & 36.2 & 57.4 & 6.4 & 25.4 & 56.3 & 18.3 \\
\hline \multicolumn{7}{|c|}{$\begin{array}{l}\text { French Level of head of } \\
\text { household }\end{array}$} \\
\hline Yes & 27.4 & 58.9 & 13.7 & 23.3 & 43.8 & 32.9 \\
\hline No & 38.4 & 54.3 & 7.2 & 23.9 & 60.1 & 15.9 \\
\hline \multicolumn{7}{|l|}{$\begin{array}{l}\text { Secondary activity of } \\
\text { head of household }\end{array}$} \\
\hline Yes & 20.8 & 62.5 & 16.7 & 11.5 & 53.8 & 34.6 \\
\hline No & 35.7 & 55.7 & 8.6 & 25.4 & 54.6 & 20.0 \\
\hline \multicolumn{7}{|l|}{$\begin{array}{l}\text { Father or Grandfather } \\
\text { get biggest piece of } \\
\text { chicken }\end{array}$} \\
\hline Yes & 35.1 & 55.8 & 9.1 & 21.4 & 61.7 & 16.9 \\
\hline No & 34.5 & 54.5 & 10.9 & 29.8 & 35.1 & 35.1 \\
\hline \multicolumn{7}{|l|}{ Age } \\
\hline$<15$ years & 50.0 & 50.0 & 0.0 & 12.5 & 50.0 & 37.5 \\
\hline $15-17$ years & 32.7 & 56.0 & 11.3 & 25.2 & 55.0 & 19.9 \\
\hline 18 years or more & 32.4 & 59.5 & 8.1 & 24.3 & 56.8 & 18.9 \\
\hline \multicolumn{7}{|l|}{ Religion } \\
\hline Muslim & 31.3 & 60.0 & 8.7 & 22.6 & 53.9 & 23.5 \\
\hline Christian & 64.9 & 0.0 & 35.1 & 25.0 & 55.2 & 19.8 \\
\hline
\end{tabular}




\begin{tabular}{lrrr|rrr} 
Yes & 23.1 & 61.5 & 15.4 & 38.5 & 38.5 & 23.1 \\
No & 35.4 & 55.6 & 9.1 & 22.7 & 55.6 & 21.7 \\
Access to Electricity & & & & & & \\
Yes & 7.7 & 84.6 & 7.7 & 30.8 & 46.2 & 23.1 \\
No & 36.4 & 54.0 & 9.6 & 23.2 & 55.1 & 21.7 \\
& & & & & &
\end{tabular}

Water Pathogens Presence in Water Samples

The samples from the water sources were analyzed after 24 hours of incubation. Drinking water is unsafe if there is a single coliform or E. coli present in $100 \mathrm{ml}$ sample according to the World Health Organization (WHO) standards. The presence of a single fecal bacterium on a petrifilm classified the water source as contaminated [62]. Figure 12 shows the results of three water sources after rainy season. Water source 8 shows no contamination of coliform or E. coli. Source 9 and 10 are contaminated with coliform and E. coli (Figure 12). Table 4 reflects this finding by giving a $\mathrm{N}$ where neither fecal bacteria was present and gives a $\mathrm{Y}$ if either is present in a water source.

All water sources were categorized by type of water source (pump or man-made lake) and by location relative to the secondary school ground. Contamination of the sources was measured using the WHO standards that state if any fecal bacteria (Coliform or E. coli) are grown on the plate, it is contaminated for drinking water standards [63]. Contamination was given a $\mathrm{Y}$ if contaminated or $\mathrm{N}$ if a fecal bacterium was not present. Then the water sources were ranked using average counts of bacteria colonies on the petrifilms. Table 4 ranks the fecal presence in different water sources from most contaminated (1) to least contaminated (10).

Source 1, the man made lake, was the most visibly contaminated with a clarity test of less than $1 \mathrm{~mm}$ visibility. This source also had the highest number of Coliform and E. coli present in the samples (mean fecal count in dry season $=544 \pm 20$, rainy season $=98 \pm 11.5$ ). 
The second most contaminated sources during the dry seasons were the two located on the school grounds, sources 9 and 10 (mean count for source $9=110 \pm 14.1$, mean count source $10=79 \pm 14.7)$.

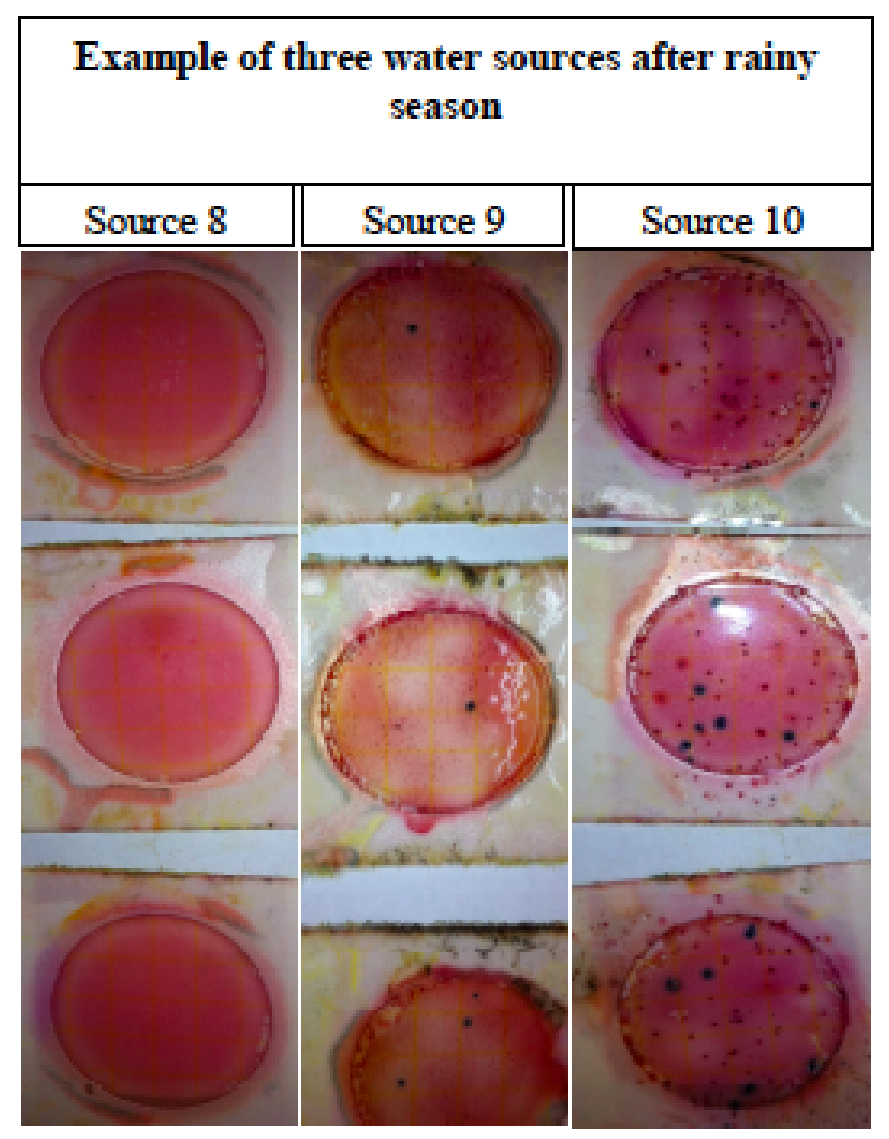

Figure 12. Examples of varying levels of coliform (red) colonies and E. coli (blue) colonies presence in the samples from three different water sources.

Water sources near the mosque and health center maintain relatively low counts of fecal bacteria during dry and rainy season (mean count source $3=1.25 \pm 0.83$, mean count source $7=0.75 \pm 0.5$ ). Two water sources, Source 2 and 8 , had no fecal bacteria in dry season. Source 6 and 8 had the lowest total fecal count across the seasons averaging close to zero. The majority of the water sources ( $80 \%$ of sources) had fecal bacteria present at the end of dry season and at the beginning of rainy season. 
Table 4. Water sources near the secondary school in the commune of Guiba and their level of contamination with fecal bacteria. Water sources were ranked by average counts of fecal bacteria from greatest to lowest (1-10 respectively). $\mathrm{Y}=$ contamination of the water source with fecal bacteria, $N=$ no detections of fecal bacteria. The location relative to the school is given and the type of water source (pump or man made lake).

\begin{tabular}{|c|c|c|c|c|c|}
\hline $\begin{array}{c}\text { Fecal bacteria } \\
\text { presence } \\
\text { ranking over the } \\
\text { year }\end{array}$ & $\begin{array}{c}\text { Water Source } \\
\text { Number }\end{array}$ & $\begin{array}{c}\text { Water Source } \\
\text { Type }\end{array}$ & Location & Dry Season & $\begin{array}{l}\text { Rainy } \\
\text { Season }\end{array}$ \\
\hline 1 & 1 & man made lake & $<1 \mathrm{~km}$ & $\bar{Y}$ & $\bar{Y}$ \\
\hline 2 & 9 & pump & school ground & $\mathrm{Y}$ & $\mathrm{Y}$ \\
\hline 3 & 10 & pump & school ground & $\mathrm{Y}$ & $\mathrm{Y}$ \\
\hline 4 & 4 & pump & $500 \mathrm{~m}$ in forest & $\mathrm{Y}$ & $\mathrm{Y}$ \\
\hline 5 & 5 & pump & $\begin{array}{c}300 \mathrm{~m} \text { near main } \\
\text { road }\end{array}$ & $\mathrm{Y}$ & $\mathrm{Y}$ \\
\hline 6 & 3 & pump & $\begin{array}{c}800 \mathrm{~m} \text { near } \\
\text { health center }\end{array}$ & $\mathrm{Y}$ & $\mathrm{Y}$ \\
\hline 7 & 7 & pump & $\begin{array}{l}700 \mathrm{~m} \text { in } \\
\text { mosque }\end{array}$ & $\mathrm{Y}$ & $\mathrm{Y}$ \\
\hline 8 & 2 & pump & $\begin{array}{c}600 \mathrm{~m} \text { near } \\
\text { market }\end{array}$ & $\mathrm{N}$ & $\mathrm{Y}$ \\
\hline 9 & 6 & pump & $\begin{array}{l}550 \mathrm{~m} \text { in farm } \\
\text { fields }\end{array}$ & $\mathrm{Y}$ & $\mathrm{N}$ \\
\hline 10 & 8 & pump & $\begin{array}{c}400 \mathrm{~m} \text { in } \\
\text { orphanage }\end{array}$ & $\mathrm{N}$ & $\mathrm{N}$ \\
\hline
\end{tabular}

\section{DISCUSSION}

This study provides a description of how seasonality, socio-economic status, culture, and water contamination as possible issues for the health and nutrition of schoolchildren living in the commune of Guiba. Each part of the discussion offers a possible form of intervention that could be pursued to aid the health of Guiba's schoolchildren. 


\section{Seasonality and Nutrition}

Seasonality had a relatively predictable relation to food availability over the two-years of market observations. There was a decrease in energy sources (cereals, tuber, and roots) during hunger season (April to mid-October). A lower number of other vegetables (e.g. onions, corn, okra, peppers, squash, carrots, eggplant, and cucumbers) were also sold during hunger season. Fruits and green leafy vegetables did not decrease during hunger season. Vendors selling fruit were most prevalent at the beginning of hunger season (April). The number of vendors selling green leafy vegetables increased during hunger season when the rains started falling (June).

Savy et al. 2006 described hunger season (cereal shortage) as a time of decreased DDS, high rate of mortality, and decreased BMI due to increased work needed to plant with a decreased cereal intake [26]. However, the results of my research supported DominguezSalas et al. 2013 finding that low DDS diet with more nutritious food items is better for women's nutritional status than high carbohydrate diets that were largely consumed during harvest season [38]. Therefore, these women were consuming a less diverse diet with higher nutritional value per food item versus a high DDS diet lacking in micronutrients $[59,60]$. The lack of other high nutritional value items was observed in the market of Guiba during hunger season which points to an opportunity to intervene. An intervention could be conducted to promote drying, canning, and other preservation techniques which increase access to diverse foods year-round.

\section{Socio-economic Status}

In the commune of Guiba, locally grown food was less expensive than food items that were processed and shipped into village. Consequently, only individuals who had more monetary wealth were able to afford food from outside of village. These individuals tended to government workers and were typically not subsistence farmers. In Guiba there was pride when one showed they had enough money to buy expensive food and not local food. The majority of schoolchildren from a higher socio-economic class (their parents were not subsistence farmers) tended to buy their food in the regional capitol where there was more variety and less local food products. 
Government workers, unlike most villagers who were subsistence farmers, did not search for green leafy vegetables in the forest during rainy season. The schoolchildren of the government workers, therefore, did not consume a prime source of vitamin A when many other nutritional sources were depleted. For example, one schoolchild of a government worker wrote that he only ate couscous and oil for a meal at the end of hunger season; this meal reflects energy sources but is less nutritious than a dish made with multiple different types of leaves $[64,65]$. This may suggest that during rainy or hunger season, poor people consumed a greater number of micronutrients than the rich. An educational intervention about the nutritional value of locally available foods could benefit individuals who view eating local meals as less prestigious.

\section{Culture: Hierarchy and Gender Roles}

Previous studies have documented family units eating habits from a communal bowl in Burkina Faso [26, 27]. However, these previous studies fail to address the innate hierarchy present in the communal eating settings. Many families divide dishes into three separate communal bowls: a bowl for the men, the women, and the children (personal observations). Almost all the schoolchildren (91\%) reported that the male head of household would always receive the largest piece of chicken. Therefore, it is possible the hierarchy in the family is related to better nutritional food consumption. The majority of schoolchildren (68\%) in this study also reported that they were served food after everyone else in the family had eaten. Eating after everyone else was usually associated with getting the scraps from the main dish (personal observations). The order in which the food is served could be associated with nutritional intake of food and is a possible area of study in the future.

Gender roles are also very strong in the commune of Guiba. All of the schoolchildren reported that only women prepared meals; when asked for clarification the school children often responded, "men do not cook because that is a woman's job" [survey and personal observations]. The roles of men and women could be related to the number of 
women who terminate their education early because the education of males is prioritized in the Mossi culture [1]. Higher educated mothers seemed to be associated with high DDS of schoolchildren that suggests increasing the education of women, especially mothers, could be a plausible form of intervention to improve nutritional outcomes.

\section{Water Contamination and Health}

Schoolchildren's exposure to waterborne pathogens from their water sources could be associated with increased prevalence of disease in the commune of Guiba. Waterborne pathogens can cause diarrhea, vomiting, dysentery, polio, hepatitis, roundworms, and tapeworms; all of which induce malnutrition [10]. These diseases have also been related to poor water and hygienic practices $[10,61,62]$. Schoolchildren reported that few people use latrine's within their villages; instead, most people defecated on the ground. Latrine use was most infrequent among children (77.7\% of children not using the latrine) and relatively uncommon among adults ( $85 \%$ of adults not using the latrine).

Coliform bacteria can be used as indicators of pathogens in water sources; the presence of certain types of coliform indicated feces and sewage in the water source [10, 62]. Fecal coliform is found in the intestines of warm-blooded animals and humans [10]. Public defecation (defecation on the ground) increases soil born pathogens that create more pathogens in the water sources and therefore more illness [10]. Eighty percent of diseases in Burkina Faso are caused by waterborne illnesses [9]. Diarrhea is the most common contributor of malnutrition by increasing the breakdown of metabolic energy stored while simultaneously decreasing food intake and nutrient absorption [61].

Almost all of the water sources within 3 kilometers of the secondary school were contaminated with fecal bacteria ( $80 \%)$. Most schoolchildren ( $92 \%$ of schoolchildren) drank from contaminated sources. The two water sources located on the school ground were some of the most polluted water sources in Guiba (school ground source 9: 110 coliform count, school ground source 10: 79 E.coli and coliform count). The few individuals who reported drinking water from wells in their courtyards $(8 \%)$ and from the 
made made lake less than a kilometer from the school grounds $(0.5 \%)$ are even more likely to be exposed to high levels of coliform and E. Coli. Water quality control and education about water contamination issues are two viable ways to stop the viscous cycle of contamination and infection [26]. As an intervention method, I communicated these findings to the mayor of Guiba, village elders, and the school to ensure they were informed about the options for improving water quality.

\section{CONCLUSION}

This analysis gave a multi-faceted description of the environmental, social, and cultural influences that could be related to malnutrition and health of the schoolchildren that attended secondary school in Guiba, Burkina Faso. The analysis suggests that water contamination of the water sources ( $80 \%$ contamination) near the secondary school could be associated with deleterious impacts on the health of school children since more than $92 \%$ report drinking water from these water sources. Education of mothers could be related to the nutritional status of schoolchildren since schoolchildren with higher DDS also tended to have educated mothers. Vendors in market showed an overall decrease during the hunger months in everything except green leafy vegetables that became more numerous while cereal became more elusive. The discussion from the aggregate data collected during the twenty-seven months implicated multiple areas of intervention that could be pursued to improve the nutritional status of the schoolchildren attending secondary school in Guiba, Burkina Faso. These possibilities include access to clean drinking water, better access of females (including mothers) to education, better food preservation techniques to aid with food access year-round, and education around preparation of healthy local foods. 


\section{WORKS CITED}

1. 1. Burkina Faso, Embassy of the United States of America, "Education" N.p., n.d. Web 1 Oct. 2014

2. Burkina Faso 2005: Findings on the Worst Forms of Child Labor. Bureau of International Labor Affairs, U.S. Department of Labor (2006).

3. $\quad$ CIA World Factbook. "Central Intelligence Agency." CIA. N.p., n.d. Web. 20 Apr. 2013.

4. $\quad$ Continentenero.it “Mappa Burkina Faso.” N.p., n.d. Web 30 September 2014

5. Committee de villageois de développement de la commune de Guiba, 2008.

6. De Longueville, F., Ozer, P., Doumbia, S., \& Henry, S. (2012), Desert dust on human health: An alarming worldwide reality and a need of studies in West Africa. International Journal of Biometeorology

7. Drechsel, P., D. Kunze and F. P. Devries (2001): Soil nutrient depletion and population growth in sub-Saharan Africa: A Malthusian nexus? Population and Environment. 22, 4, 411423.

8. $\quad$ "Eau, Hygiène Et Assainissement." UNICEF Burkina Faso. N.p., n.d. Web. 25 Apr. 2013

9. $\quad$ "Encyclopedia of the Nations." Environment. N.p., n.d. Web. 20 Apr. 2013.

10. Epi Public Health NC Government, "Coliform Bacteria” N.p., n.d. Web 08 Feb. 2016

11. G.B. Keding et al. 2012. "Relating dietary diversity and food variety scores to vegetable production and socio-economic status of women in rural Tanzania." Food Security 4 (1), 129-140

12. GlobalTwitcher.com "Painted Hunting Dog: Lycaon pictures" C. Michael Hogan 2009. N.p., n.d. 15 Aug. 2014

13. Hale, M. (2005). Weather patterns, food security and humanitarian response in subSaharan Africa. Phylisophical Transactions of the Royal Society, B, 360, 2169-2182.

14. Henry, Sabine, et al. "Descriptive analysis of the individual migratory pathways according to environmental typologies." Population and Environment 25.5 (2004): 397-422.

15. Henry, Sabine, Bruno Schoumaker, and Cris Beauchemin. "The impact of rainfall on the first out-migration: A multi-level event-history analysis in Burkina Faso." Population and Environment 25.5 (2004): 423-460.

16. History World, "HISTORY OF BURKINA FASO" N.p., n.d. Web 1 Oct 2014

17. $\quad$ "Indexmudi.com." Indexmudi.com. N.p., n.d. Web. 20 Apr. 2013.

18. INSD. (2000). Analyse des Resultats de Recensement General de la Population et de L'Havitation de 1996. Ouagadougou: Institut National de la Statistique et de la Demographie.

19. Intervida.org "The reality of education in Burkina Faso" N.p., n.d. Web 1 Oct. 2014 
20. Lewis, M. Paul (ed.), 2009. "Languages of Burkina Faso" Ethnologue: Languages of the World, Sixteenth edition. Dallas, Tex.; SIL International.

21. $\quad$ Maps and 7 Flags." NationMaster.com. NationMaster, n.d. Web. 25 Apr. 2013.

22. Mathieu, P. 1994. Mouvements de Population et Transformations Agricoles: le Cas du Burkina Faso. In P.-J. Laurent, P. Mathieu, \& M. Totte (Eds.). Migrations et Acces a la Terre au Burkina Faso (pp. 17-40). Louvain-la Neuve/Paris: Academia/L'Harmattan.

23. McMichael, A. J. 2003. Global climate change: Will it affect vector-borne infectious diseases? International Medical Journal, 33(12), 554-555.

24. M. Faber, C. Schwabe and S. Drimie 2009. "Dietary diversity in relation to other household food security indicators." International Journal of Food Safety, Nutrition and Public Health, 2(1), 2009

25. Miaffo et al. 2004 "Malaria and anemia prevention in pregnant women of rural Burkina Faso." BMC Pregnancy and Childbirth 2004, 4(18), 1-7

26. Muller, O., and Krawinkel, M. 2005 "Malnutrition and health in developing countries." CMAJ Aug. 2, 2005; 173(3)

27. Oxfam. “Oxfam's Cool Planet- Food in Burkina Faso.” N.p., n.d. Web October 2, 2014.

28. Pare' S, So"derberg U, Sandewall M, Ouadba JM. 2008. "Land use analysis from spatial and field data capture in southern Burkina Faso,West Africa." Agriculture, Ecosystems \& Environment 127: 277-285.

29. Population and Environment Course. Kristine Nachbor. Michigan Technological University.

30. Poston, Dudley L., and Leon F. Bouvier. Population and Society: An Introduction to Demography. New York: Cambridge UP, 2010. Print.

31. $\quad$ "PRB's Interactive Map." 2012 World Population Data Sheet - 2012 Global Population Data. N.p., n.d. Web. 20 Apr. 2013.

32. Quisumbing, A., Brown, L., Felstein, H., Haddad, L., and Pena, C. 1995. "Women: The Key To Food Security." Food Policy Report: The International Food Policy Research Institute.

33. Reuters News "Burkina Faso referendum call hints at leader's re-election bid" N.p., n.d. Web 14 April 2014

34. Roncoli, C., Ingram, K., \& Kirshen, P. 2001. "The costs and risks of coping with drought: Livelihood impacts and farmers' responses in Burkina Faso." Climate Research, 19(2), 119-132.

35. Sauerborn, R., Nougatara, A., Hien, M., \& Diesfel ,H.J 1996 "Seasonal variations of household costs of illness in Burkina Faso" Social Science \& Medicine, 43(3), 281-290

36. Savy et al, 2005. "Use of variety/diversity scores for diet quality measurement: relation with nutritional status of women in a rural area in Burkina Faso" European Journal of Clinical Nutrition 59, 703-716 
37. Savy et al, 2006. "Dietary Scores and Nutritional Status of Women Change during the Seasonal Food Shortage in Rural Burkina Faso." The Journal of Nutrition 136, 2625-2632

38. Santos D. S. and Henry J. F. S. 2007. "Rainfall variations and child mortality in Sahelian region: Results from comparative event history analysis in Burkina Faso and Mali." Union for African Population, Fifth African Population Conference.

39. “SIM Country Profile: Burkina Faso.” web.archive.org. N.p, n.d, Web 29, Sept. 2014.

40. SP Sawadogo, 2002. Pratiques alimentaire dans la province de la Gnagna. Me'moire de DEA Universite' de Ouagadougou, 64.

41. Statistics on Burkina Faso. Facts and Figures, Stats and Information on Burkinabe Economy, Crime, People, Government, Health and Education. 9

42. $\quad$ "The World's Water." Where Is Earth's Water? USGS Water-Science School. N.p., n.d. Web. 25 Apr. 2013.

43. "The World Bank." World Bank Search. N.p., n.d. Web. 20 Apr. 2013.

44. Unicef, Burkina Faso Education Issue Overview, "Raise the rate of children in full-time education" N.p., n.d. Web 1 Oct 2014

45. USA Census “Average household size” N.p., n.d. Web. 08 Feb. 2016

46. WFP United Nations World Food Programme "Burkina Faso" WFP United Nations N.p., n.d. Web. 15 Aug. 2014

47. Wikimedia.org "Burkina Faso in Africa" N.p., n.d. Web 30 September 2014

48. Worldtravelguide.net "Burkina Faso History, Language, and Culture" N.p., n.d. Web 2 Oct. 2014

49. Burkina Faso Volunteer Manual- Peace Corps. "Peace Corps Burkina Faso Volunteer Manual of Policies and Procedures." A Peace Corps Publication 2014

50. Planete-Burkina.com, 2009 "Local Languages" N.p., n.d. Web 2 Oct. 2014

51. Bbc.com, 2016 "Burkina Faso profile-Timeline” N.p., n.d, Web 23 Feb 2016

52. Dabone et al. 2011 "Poor nutritional status of schoolchildren in urban and peri-urban areas of Ouagadougou (Burkina Faso).” Nutritional Journal 10. 1186/1475-2891

53. Doctorswithoutborders.org "Malnutrition: Latest MSF Updates" N.p., n.d Web Feb 2016

54. Krukowski et al. 2010 "Neighborhood Impact on Healthy Food Availability and Pricing in Food Stores” J Community Health 35(3): 315-320

55. Bbc. com "Egypt heat wave leave 61 people dead” Np., n.d Web Feb 2016

56. O'hara et al. 1982 "Parental Education and child health: Intracountry evidence" Health Policy and Education 2(4) 213-250

57. Brainerd and Menon, 2015 "Religion and Health in Early Childhood: Evidence from South Asia" Population and Development Review 41(3), 439-463 
58. Pbr.org "Nutrition of Women and Adolescent Girls: Why It Matters" Ransom and Elder, 2003 N.p., n.d Web Feb 2016

59. Dominguez-Salas et. al 2015 "DNA methylation potential: dietary intake and blood concentrations of one-carbon metabolites and cofactors in rural African women" Genome Biology 16: 118

60. Bbc.com "The amazing significance of what a mother to be eats" N.p., n.d Web 14 Sep 2015

61. Ncbi.nlm.nih.gov/books/NBK219 "Nutritional Consequences of acute Diarrhea" National Research Council (US) Subcommittee on Nutrition and Diarrhea Diseases Control. Nutritional Management of Acute Diarrhea in Infants and Children. Washington (DC): National Academies Press (US); 1985.

62. World Health Organization (WHO) 2001. "Water Quality: Guidelines, Standards and Health." World Health Organization Water Quality Guidelines 2, 17-42

63. Food and Agriculture Organization of the United Nations (FAO), 2010. "Guidelines for measuring household and individual dietary diversity." Food and Agriculture Organization of the United Nations, 5-51

64. Stadlmayr et al. 2012 "West African Food Composition Table; Table de composition des aliments d'Afrique de l'Ouest" Nutrition Programmes Service, Food and Nutrition Division, FAO, Rome, 1-171

65. Lopriore et al. 2003 "Food Security and Nutrition Trends in West Africa-Challenges and the Way Forward" Nutrition Programmes Service, Food and Nutrition Division, FAO, Rome, 1-24 
APPENDIX A: MARKET OBSERVATON SURVEY TEMPLATE

\begin{tabular}{|c|c|c|c|c|c|}
\hline AVALIA & & & & & \\
\hline \multicolumn{6}{|c|}{ Location: } \\
\hline \multicolumn{6}{|c|}{ Date of Survey: } \\
\hline & & & \multicolumn{3}{|c|}{ Quality of Food } \\
\hline Fruits & \# Vendors & $100 \mathrm{cfa}$ & Poor & Medium & High \\
\hline mangos ( & & & & & \\
\hline tomatos & & & & & \\
\hline avacado & & & & & \\
\hline papaya & & & & & \\
\hline limes & & & & & \\
\hline bananas & & & & & \\
\hline guava & & & & & \\
\hline qualitie & & & & & \\
\hline wada & & & & & \\
\hline watermel & & & & & \\
\hline grapes & & & & & \\
\hline pinapple & & & & & \\
\hline strawberr & & & & & \\
\hline apples & & & & & \\
\hline grapefruit & & & & & \\
\hline oranges & & & & & \\
\hline tangerine & & & & & \\
\hline tangalos & & & & & \\
\hline moringa & & & & & \\
\hline
\end{tabular}




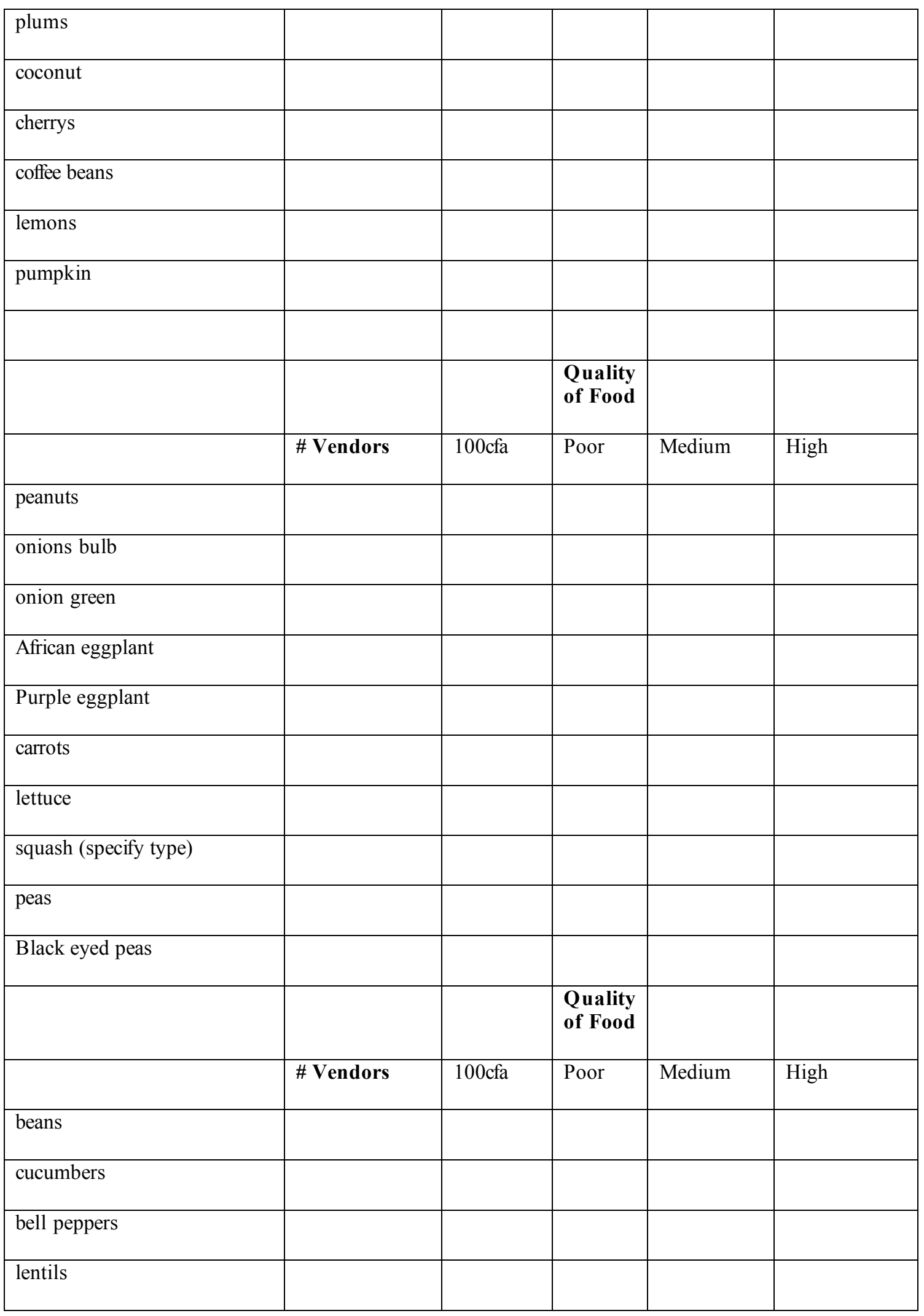




\begin{tabular}{|c|c|c|c|c|c|}
\hline \multicolumn{6}{|l|}{ potatoes } \\
\hline \multicolumn{6}{|l|}{ yams } \\
\hline \multicolumn{6}{|l|}{ garlic } \\
\hline \multicolumn{6}{|l|}{ ginger } \\
\hline \multicolumn{6}{|l|}{ green beans } \\
\hline \multicolumn{6}{|l|}{ pema (hot pepper) } \\
\hline \multicolumn{6}{|l|}{ leaves (type if possible) } \\
\hline & & & $\begin{array}{l}\text { Quality } \\
\text { of Food }\end{array}$ & & \\
\hline Grains & \# Vendors & $100 \mathrm{cfa}$ & Poor & Medium & High \\
\hline \multicolumn{6}{|l|}{ corn solid } \\
\hline \multicolumn{6}{|l|}{ corn flour } \\
\hline \multicolumn{6}{|l|}{ millet solid } \\
\hline \multicolumn{6}{|l|}{ millet flour } \\
\hline \multicolumn{6}{|l|}{ gateaux } \\
\hline \multicolumn{6}{|l|}{ gallet } \\
\hline \multicolumn{6}{|l|}{ achechai } \\
\hline \multicolumn{6}{|l|}{ bean cakes } \\
\hline \multicolumn{6}{|l|}{ soybeans (tofu, soymilk) } \\
\hline & & & $\begin{array}{l}\text { Quality } \\
\text { of Food }\end{array}$ & & \\
\hline Meat/Animal Products & \# Vendors & $100 \mathrm{cfa}$ & Poor & Medium & High \\
\hline \multicolumn{6}{|l|}{ Pig } \\
\hline \multicolumn{6}{|l|}{ Chicken } \\
\hline \multicolumn{6}{|l|}{ Pintard } \\
\hline Sheep & & & & & \\
\hline
\end{tabular}




\begin{tabular}{|l|l|l|l|l|l|}
\hline Cow & & & & & \\
\hline Chicken Eggs & & & & & \\
\hline Pintard Eggs & & & & & \\
\hline Milk (goat/cow) & & & & & \\
\hline Cheese & & & & & \\
\hline Dried Fish & & & & & \\
\hline Fresh Fish & & & $\begin{array}{l}\text { Quality } \\
\text { of Food }\end{array}$ & & \\
\hline Seasoning & \# Vendors & $100 \mathrm{cfa}$ & Poor & Medium & High \\
\hline buerre de qualitie & & & & & \\
\hline $\begin{array}{l}\text { Maggi, Jumbo etc. (specify } \\
\text { type) }\end{array}$ & & & & & \\
\hline
\end{tabular}

\section{APPENDIX B: CULTURAL SURVEY}

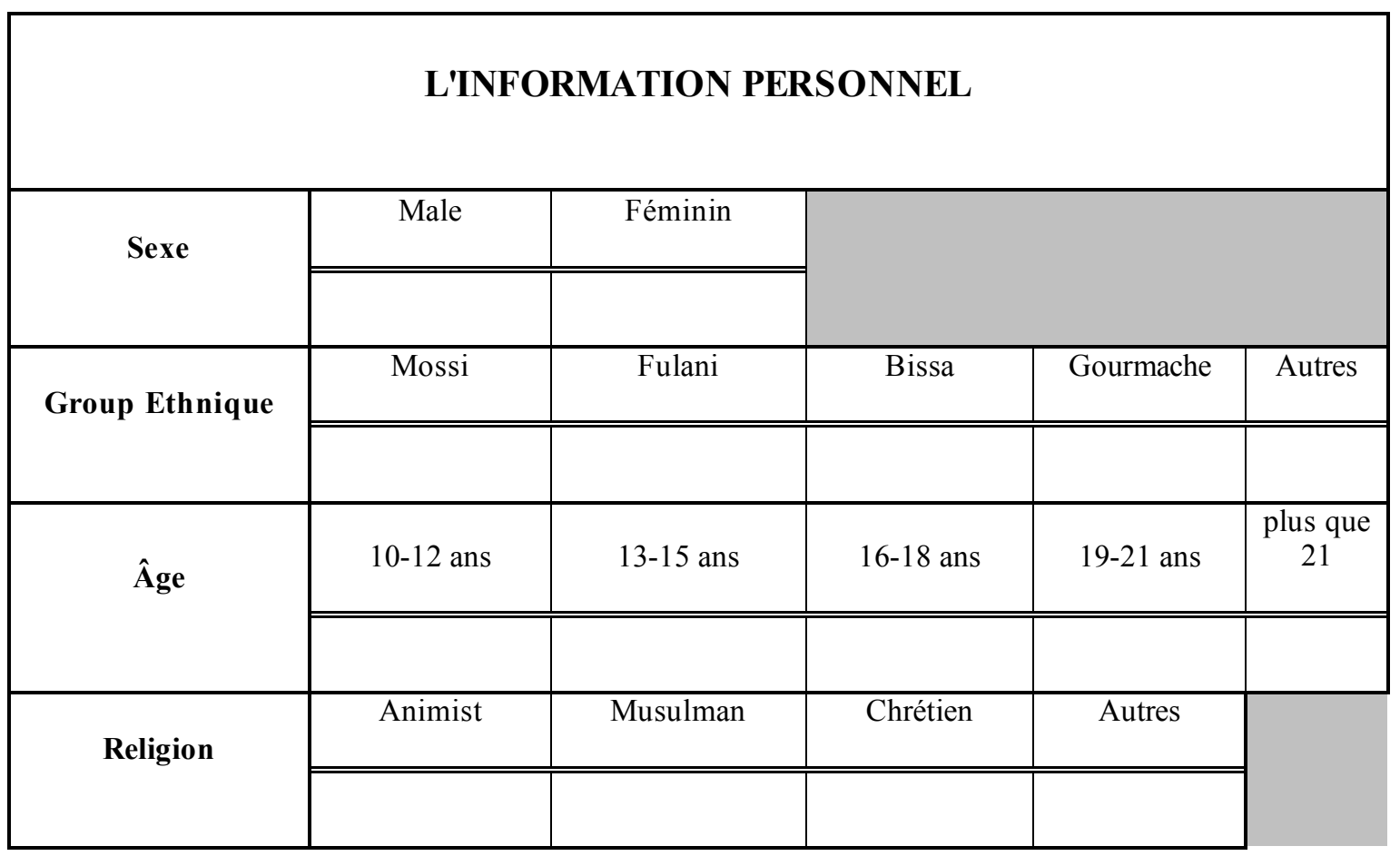




\begin{tabular}{|c|c|c|c|c|c|c|c|}
\hline Résident Statut & \multicolumn{2}{|c|}{ Village natal } & $\begin{array}{l}\text { Village pendant } \\
\text { vacance }\end{array}$ & \multicolumn{2}{|c|}{$\begin{array}{l}\text { Village } \\
\text { pendant l'anee } \\
\text { scholar }\end{array}$} & & \\
\hline \multicolumn{8}{|c|}{ COMPOSITION FAMILIALE } \\
\hline \multicolumn{2}{|c|}{$\begin{array}{l}\text { Dessin votre cour. Expliquez } \\
\text { le nombre des } \\
\text { personne(s)/chambre(s) dans } \\
\text { chaque maison. }\end{array}$} & & & & & & \\
\hline \multicolumn{2}{|c|}{$\begin{array}{c}\text { Qui est la personne le plus } \\
\text { agé chez-toi ? }\end{array}$} & & & & & & \\
\hline $\begin{array}{r}\text { Quelles sont le } \\
\text { d'éducation des } 1 \\
\text { la famill }\end{array}$ & $\begin{array}{l}\text { eau } \\
\text { pres de }\end{array}$ & Père & Grand & père & Mère & $\begin{array}{l}\text { Grand- } \\
\text { mère }\end{array}$ & $\begin{array}{c}\text { Les } \\
\text { autres qui } \\
\text { vivre } \\
\text { avec toi }\end{array}$ \\
\hline \multicolumn{8}{|c|}{ Aucun niveau } \\
\hline \multicolumn{8}{|c|}{ L'école Primaire } \\
\hline \multicolumn{8}{|l|}{ CEP } \\
\hline \multicolumn{8}{|c|}{ 6ieme, 5ieme, 4ieme, 3 ieme } \\
\hline \multicolumn{8}{|l|}{ BEPC } \\
\hline \multicolumn{8}{|c|}{ 2nd, 1 ier, terminale } \\
\hline \multicolumn{8}{|l|}{ BAC } \\
\hline Univers & & & & & & & \\
\hline
\end{tabular}




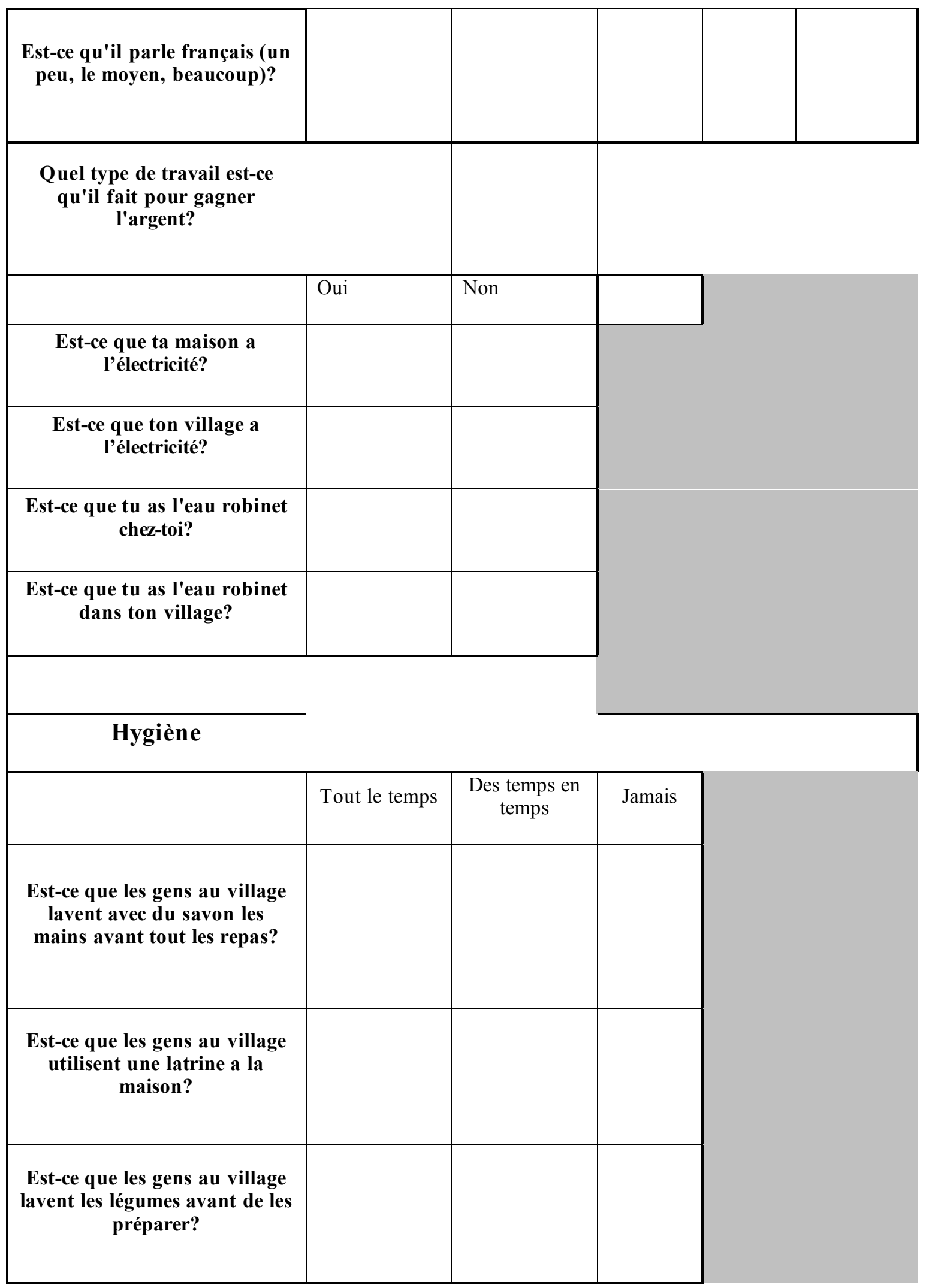




\section{DISPONIBILITÉ}

La classe va faire un calendrier qui expliquez quel mois on peut trouver les different types des nourriture

\begin{tabular}{|c|c|c|c|c|c|}
\hline \multirow[t]{2}{*}{ ACCESSIBILITÉ } & \multirow[b]{2}{*}{$\begin{array}{l}\text { Tout le } \\
\text { temps }\end{array}$} & \multirow[b]{2}{*}{$\begin{array}{c}\text { Des temps } \\
\text { en temp }\end{array}$} & \multirow[b]{2}{*}{ Jamais } & \multirow[b]{2}{*}{ Oui } & \multirow[b]{2}{*}{ Non } \\
\hline & & & & & \\
\hline \multicolumn{6}{|l|}{ Manges- tu chaque jour? } \\
\hline \multicolumn{6}{|l|}{1 fois par jour? } \\
\hline \multicolumn{6}{|l|}{2 fois par jour? } \\
\hline \multicolumn{6}{|l|}{3 fois par jour? } \\
\hline \multicolumn{6}{|l|}{ Plus que trois fois? } \\
\hline \multicolumn{6}{|l|}{$\begin{array}{l}\text { Expliquer l'ordre de qui } \\
\text { mange premier et le dernier } \\
\text { dans ta famille. }\end{array}$} \\
\hline \multicolumn{6}{|l|}{$\begin{array}{l}\text { Si on a eu une seul poulet, } \\
\text { qui (dans ton maison) va } \\
\text { gagner le plus grand } \\
\text { portion? }\end{array}$} \\
\hline $\begin{array}{l}\text { Est-ce qu'il y a un autre } \\
\text { village à côté qui a plus de } \\
\text { nourriture que ton village? }\end{array}$ & & & & & \\
\hline Ou? & & & & & \\
\hline
\end{tabular}


En quel village ta famille achète nourriture ?

\section{UTILISATION}

Normalement qui prépare

les repas?

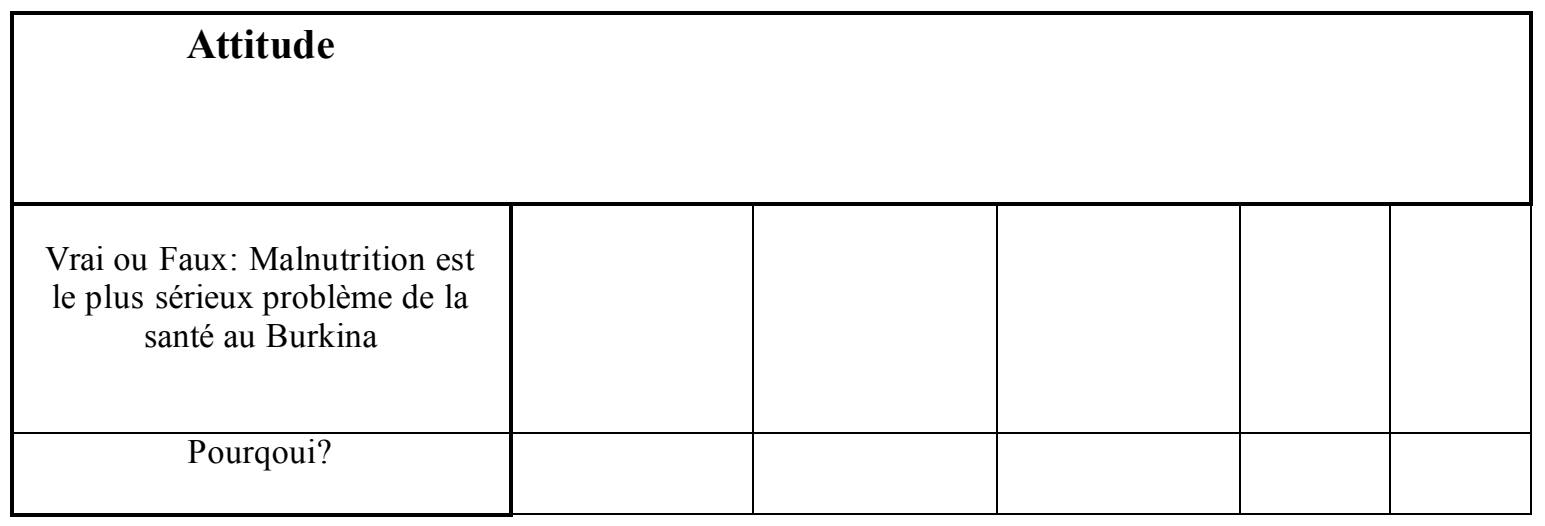

\section{Pratique}

Avec quel maladies et a quel moment tu va cherché l'aide au CSPS?

Est-ce que tu as mangé Plummy ?

\begin{tabular}{|l|l|l|l|l|}
\hline & & & & \\
\hline & & & & \\
\hline
\end{tabular}




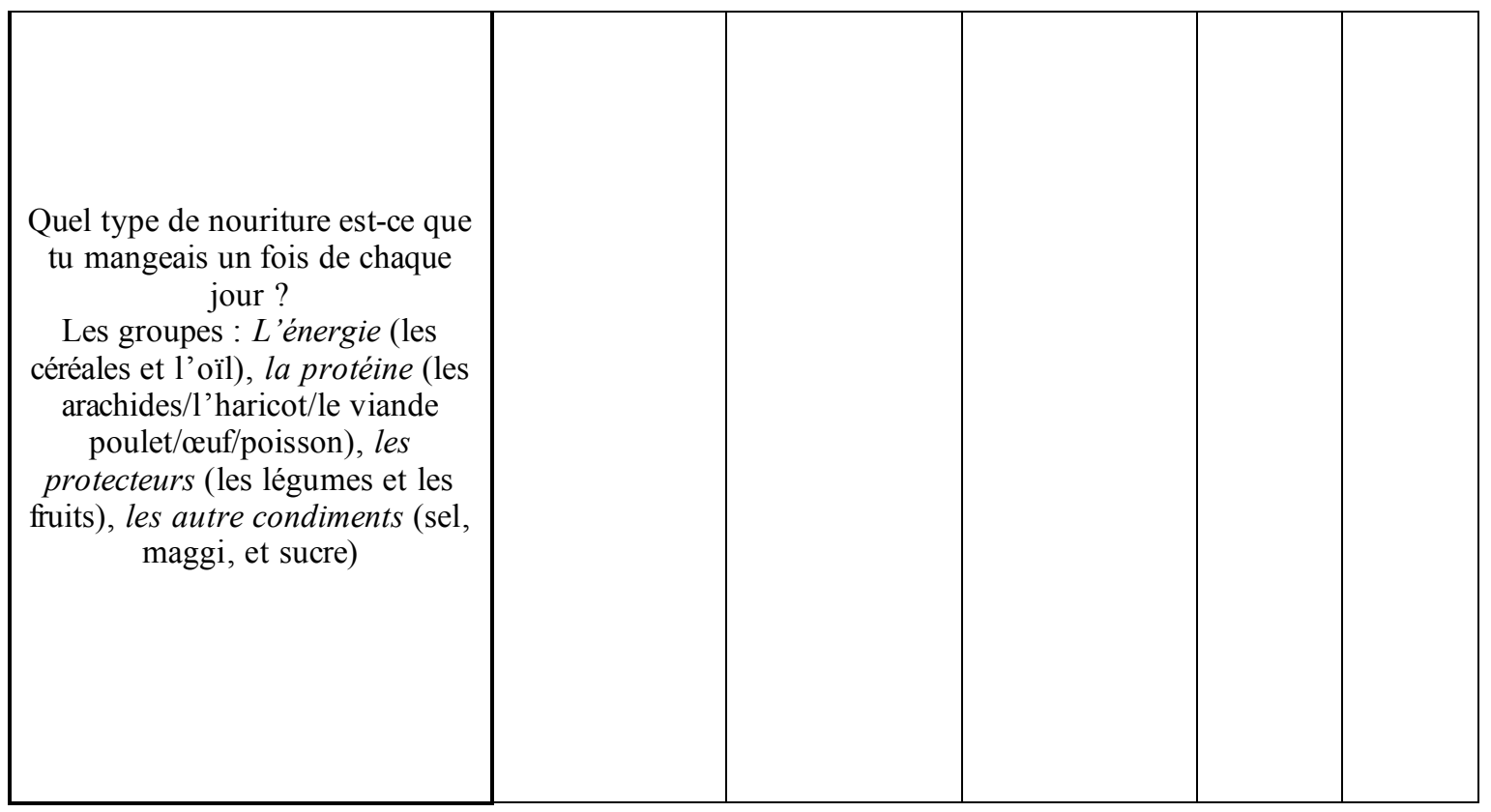

APPENDIX C: TEMPLATE AND WATER QUALITY SURVEY DATA

EXAMPLE OF RAW DATA COLLECTED

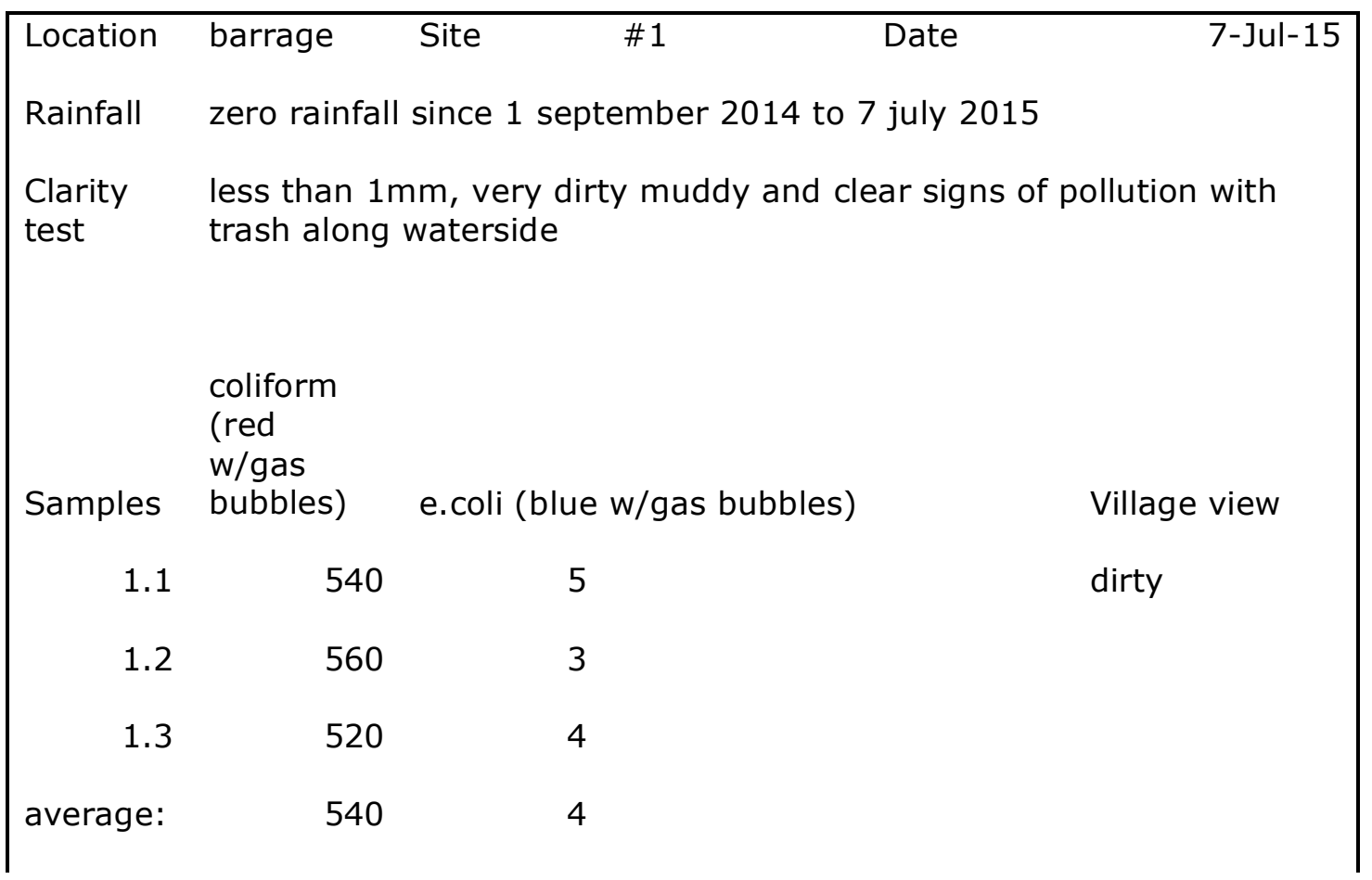




\section{APPENDIX D: ADDITIONAL INFORMATION}

\section{GEOGRAPHICAL AND MINERAL RESOURCES}

A landlocked country in Sub-Saharan Western Africa, Burkina Faso's savannah landscape is full of cultural and climatic diversity. More than 60 ethnic groups and languages exist in a country about the size of Colorado.

Burkina Faso is located $9^{\circ} 00$ and $15^{\circ} 00^{\prime} \mathrm{N}$ and $6^{\circ} 00^{\prime} \mathrm{W}$ and $3^{\circ} 00^{\prime} \mathrm{E}$. Burkina is 274,200 square kilometers with 400 square kilometers of fresh water resources, which is variable with seasonality. Burkina Faso is bordered by Ghana $(549 \mathrm{~km})$, Togo $(126 \mathrm{~km})$, Benin (306km), Niger (628km), Cote d'Ivoire $(584 \mathrm{~km})$, and Mali $(1,000 \mathrm{~km})$.

There is not much topographic diversity in the landscape; the terrain is mostly flat with savannah plains dominating the center regions and hills in the west and southeast. The highest point is Tenu Kourou in the southwest region, at $749 \mathrm{~m}$. The lowest point is Mouhoun (Black Volta) River, at 200m. The chief mineral resources are manganese, limestone, marble, small deposits of gold, phosphates, pumice and salt [3].

\section{Geographical Situation of Guiba}

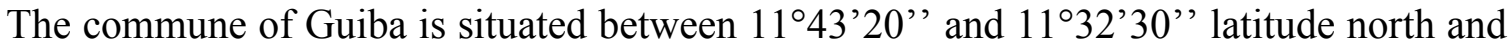
$1^{\circ} 5^{\prime} 5^{\prime \prime}$ and $1^{\circ} 16^{\prime} 40^{\prime}$ ' longitude west. Guiba is $12 \mathrm{~km}$ from Manga (the capital of the province of Zoundwéogo and the regional capitol of the center south) [5].

\section{HISTORY}

Burkina Faso means "land of upright people." It was formally known as the Upper Volta under French colonial rule. They achieved independence from France in the 1960s. Democracy was implemented in the 1990s with multiparty elections; however, there has never been a peaceful transition between presidential leaders [3]. There have been a total 
of five military coups since Burkina has become independent (in 1966, 1980, 1982, 1983, and 1987)[16] and one civilian uprising in 2014 [51].

The first president, Maurice Yameogo, was known for his corrupt and lavish lifestyle in the poor country. Overthrown in 1966, Lt-Col Lamizana became president and, although he tried, he was unable to return the government to civilian legislature. Thomas Sankara won control in 1983 and was a radical in his thinking. He was known as a grassroots reformer and was the president who changed the countries name from Upper Volta to Burkina Faso [16].

The previous president Blaise Compaore came to power with a military coup in 1987 after he killed his best friend, Thomas Sankara, to attain power [16]. Democratic elections have been introduced to Burkina Faso and Blaise COMPAORE has been elected every time for 27 years [3]. He rested in power until 2014 when he was ousted from government through a civilian uprising. After the uprising and a few months of a transitional government, Burkina Faso elected Roche Kabore on November 29, 2015 [3, $51]$.

\section{History of Guiba}

Initially, Guiba was called «Guibleba» which means in the Moore language «road block». A long time ago the people of Guiba served as security forces for those under the command of the most powerful Mossi cheif, the Mogho Naba. As a thank you to the village for being the security force of the Mossi kingdom, the Mogho Naba sent his first son to Guiba to live under the protection of the village. Today that tradition continues and the first son of the Mogho Naba must come to Guiba to live before becoming Mogho Naba. The day that the son will become Mogho Naba, he will go to Ouagadougou, where he will see his father (Mogho Naba) causing him to die and allowing the son to become the new Mogho Naba [5, stories from chief of village]. 


\section{DEMOGRAPHICS}

The population size in 2012 was around 17.5 million [31]. This population size has been dramatically increasing over the past couple of years; it has increased by about 2 million since 2010 [29, 31]. In 2010 the worldwide average natural rate of increase was $1.2 \%$. This data coincides with a doubling time of 12 years [29].

The high growth rate is accompanied by an extremely large youth dependency ratio of $86 \%$ [17], seen in the population pyramid in Figure 5. Almost half (46\%) of the population is under age 15 with $20 \%$ between fifteen and twenty-four, $28 \%$ between twenty-five and fifty-four and only $5.6 \%$ of the population is over fifty-five years [3].

Burkina Faso has the fourth highest crude birth rate (CBR) in the world; at 43.2 births per 1,000. In 2012, the total fertility rate (TFR) was about 6 children born/woman; roughly three times higher than replacement level fertility [3].

The TFR could be high for many reasons: female inequality, low education status and lack of use of contraception [30,31]. Only $16 \%$ of the population uses contraception compared to $72 \%$ of Women in developed countries and $33 \%$ of women in less developed countries [31]. Social reasons, lack of understanding or acceptance and economic reasons play into the lack of family planning in Burkina Faso $[3,30,31]$.

Maternal and child mortality rates have reduced significantly over the past 23 years although they remain relatively high at 300 maternal deaths/per 100,000 live births and 102 child deaths/1,000 live births. Burkina Faso also has the ninth highest infant mortality rate. Factors negatively affecting maternal health and birth outcomes include but are not limited to only $34 \%$ of pregnant mothers attending all four antenatal visits in pregnancy; and $67 \%$ of births attended by skilled birth attendants [49].

If infants make it past this fragile stage, the life expectancy is still low (55 years old). This falls below the world average of 70 and the average in developing countries of 59 . The low life expectancy could occur for any number of reasons: poor living situations, 
degraded environments, little education, and poor access to health care along with high risk of infectious diseases. Luckily, HIV/AIDS prevalence remains low (about 1\%) among people ages 15-49 years of age.

\section{LANGUAGE}

French remains an official language even after the end of French colonization and is the only language used to teach in secondary school, however a minority of the population speaks it fluently seeing that less than $20 \%$ finish secondary school. French is spoken mostly at administrative, political and judicial institutions; public services; and in the media. More than $90 \%$ of the population speaks one of the 60 native languages that stem from the Sudanic family and a total of 69 languages are spoken in Burkina Faso [20, 3].

The three official native languages are Moore, Fulfulde (Peuhl), Dioula [3]. The most spoken language is Moore, which is spoken by $40 \%$ of the population that lives mostly in the central region speaks this language. Dioula is spoken mostly in the southwest and Fulfulde is widespread throughout Burkina but spoken the most in the north. The Gourmache language is spoken in the east and the Bissa language is spoken in the south. Smaller local languages are spoken in specific villages and the dialects of main languages differ depending on the region [20].

The diversity of language is another colorful part of the Burkina landscape. It creates unity between the people of similar language group. However, the inability of many people to speak one of the official languages makes cross culture communication difficult.

\section{CULTURE}

Along with the many diverse languages, there is a plethora of ethnic groups that exist in Burkina Faso. Oral stories dominate the culture and each of the more than 69 ethnic groups has a story of why they are in Burkina Faso today. Often the oral traditions serve as warnings for young children or moral reminders, and warnings, of consequences that 
come if they do not heed the story's message. One such story is that of the Mossi Empire [3]. The Mossi came from the south. In their tale, a young prince from the south rode north to find more land. There he found a girl in the woods. He had a son with the girl and he named his son Ouedraogo, stallion. His son conquered all the territory known as Burkina Faso today and, some say, that is why the soccer team is named "Les etalons."

Dance is another large part of the local culture. It is used during sacrifices to appease the gods and animal spirits. When a person puts on a mask, they no longer are the person underneath; they become the mask they are wearing. In some ethnic groups, the masks are different animals and the people hope to appease this animal or gain one of the qualities this animal possesses (for example, if one wanted to be more mischievous they would make a sacrifice to a monkey spirit). In general, masks cannot be photographed because photos will capture the magic of the spirit in the mask. However, every two years one can take a photo at a traditional mask festival held in Dedegou, Burkina Faso. Even today masks are present at important ceremonies and are thought to have powers to heal, provide luck and curse locals. Each mask and dance is done for a reason: funerals, weddings, and other ceremonies will have traditional groups dancing or masks present [personal observation and Peace Corps Training sessions].

Dance is also used in religious events. Religion is an important part of a Burkinabe's life. About $7 \%$ of the population is animist, however, most people practice their animist traditions along side modern religions. $61.6 \%$ of the population identifies as Muslim and about $30 \%$ consider themselves Christian [48]. Since religion is such an important part of Burkinabe culture, traditional holidays are celebrated by all with sacrifices of animals and food available to everyone close to the family.

Food is the center of Burkinabe culture. Meetings, conferences, celebrations, and simple friendly exchanges are always accompanied with a meal. To show respect and be polite, it is important to invite anyone nearby to a meal that is being eaten before starting to eat.[personal observations] The meals are generally based around staple Western African 
foods: potatoes, beans, yams, sorghum, rice, maize, millet, peanuts, and okra. The staple dish is tô. Tô is made most commonly with maize or millet flour but can be made with sorghum flour. It is made into a paste and served with a sauce or eaten with sugar in water [27].

\section{HEALTH}

The World Health Association attributes 23\% of deaths in Africa to environmental factors [38], however, it could be argued that all factors connected to humans are tied to the environment. For example, a hotter climate and increased deforestation, increases the amount of dust, which can lead to respiratory diseases [6].

Water related diseases are shown to be associated with rainfall events; increasing disease with larger amounts of rainfall because more water leads to greater number of places for insects to lay eggs and, therefore, more communicable diseases will develop [38]. In Burkina Faso, malaria remains the primary cause of mortality and morbidity with more than 6 million cases reported in 2012, and about $75 \%$ of all malaria deaths occurring in children [49].

In Burkina Faso, generally, higher child mortality is found in regions with less rainfall [38], however, the quality and quantity of water has direct effects on agricultural production. Agriculture production influences mortality rates by varying food availability, which, in turn, impacts nutritional status of communities [Haile, 2005]. High temperatures also lead to greater speed of disease growth and development in the water [McMichael et al. 2003]. In moderate to normal rainfall in some regions (3 and 9), whose food production depends on stationary crops, there was an increased infant mortality rates (IMR). Regions that had more migratory forms of food production, such as herding and nomadic pastoralism (5, 6, and 8), had a decrease in IMR [Santoz et al. 2012].

There are many explanations for these observed differences; decreased rainfall is associated with a decrease in pathogens, however, crops maybe sensitive to the lack of 
rainfall which would lead to hunger and malnutrition later making people more susceptible to disease.

In the recent years, Western Africa has experienced a general decrease in rainfall throughout the region [15]. As shown above, this will have varied effects on the many communities in Burkina Faso. From these studies is seems that the groups practicing the migratory forms of agriculture (herding and nomadic pastoralism) will adapt better to desertification leading to better overall health since they will be able to stay nourished and, therefore, be less prone to disease.

\section{Water Sources of Guiba}

Ground water is easily accessed in the 1-3 months of rainfall by the wells and pump. The months of rainfall are known as the time for planting because many of the staple food crops are grown during this season. During dry season, the ground water sources can dry out causing many in the village to walk long distances to find water [5].

\section{AGRICULTURE AND ECONOMY}

For the past couple of years there has been a steady economic increase (economic growth rate of $5.5 \%$ ) with cotton being the leading export and source of revenue for the country. In 2012, an estimated 10\% of the GDP was due to the export of cotton and gold. That same year, despite positive economic indicators, Burkina Faso had a poverty rate of $46 \%$ and $88 \%$ of people were living on less than $2 \$$ per day. Per capita income was estimated in 2012 at $\$ 660$, and the unemployment rate is estimated at 77\% [49]. In Guiba \$2 was considered a lot of money and most people only exchanged "small money" which is equivalent to money less than 50 cents [personal observations].

\section{EDUCATION}

The introduction of the Education Act makes schooling compulsory from age 6 to 16, although it is hard to enforce this law in a country that lacks the infrastructure. The law 
also creates a size limit of 65 children in one class, however this law is often ignored, especially in rural areas where classes can contain more than 100 students [2].

The encouragement of girls in school has led to an increase in the enrollment of girls over the past couple of years. Secondary schooling is not free, and school can cost approximately $\$ 160$ per child, a price not every family can afford [1]. This is deemed to be a large developmental problem with about 70\% of Burkina Faso's population composed of youth under the age of $25[3,49]$.

\section{Education System in Guiba}

Of the total 4,775 students, $49 \%$ are female and $51 \%$ are male. Below is a table of enrollment by year of percentage of males (M) and females (F) and the percentage pass rate of each class year. One of the problems with finding teachers is that there are not enough classrooms for the teachers to work. This insufficiency is accompanied by a lack of latrines (one for two schools) and not enough clean water sources. There is only one secondary school in the commune of Guiba. The secondary school in Guiba opened October 021997 and had 274 students who enrolled for the year 2007-2008. Of those students $78 \%$ passed their BEPC.

Table 5. Percentage of Males (M) and Females (F) in school compared to pass rate of sex (Direction provinciale de l'enseignement de base (DPEBA)/Zoundwéogo, juin 2008 [5])

\begin{tabular}{|c|c|c|c|c|c|c|c|c|}
\hline & \multicolumn{2}{|c|}{$2004 / 2005$} & \multicolumn{2}{c|}{$\mathbf{2 0 0 5 / 2 0 0 6}$} & \multicolumn{2}{c|}{$\mathbf{2 0 0 6 / 2 0 0 7}$} & \multicolumn{2}{c|}{ 2007/2008 } \\
\cline { 2 - 8 } & $\mathrm{M}$ & $\mathrm{F}$ & $\mathrm{M}$ & $\mathrm{F}$ & $\mathrm{M}$ & $\mathrm{F}$ & $\mathrm{M}$ & $\mathrm{F}$ \\
\hline $\begin{array}{c}\text { Enrollment } \\
(\%):\end{array}$ & 54.9 & 51.4 & 60.1 & 57.6 & 67.9 & 63.9 & 72 & 70.2 \\
\hline $\begin{array}{c}\text { Pass Rate } \\
\text { (\%) }\end{array}$ & 86.6 & 79.6 & 86 & 77.5 & 73.6 & 67.4 & - & - \\
\hline
\end{tabular}


There are only two secondary schools in the commune of Guiba. The secondary school in Guiba opened October 021997 and had 274 students who enrolled for the year 20072008. Of those students $78 \%$ passed their BEPC.

\section{Infrastructure}

The commune of Guiba has 27 schools with a total of 86 classrooms serving 4,775 students with 90 teachers. Almost all the villages have a school but these schools vary drastically with some providing insufficient education for students because of lack of resources; not enough school rooms, teachers, and minimal material resources (books, chalk, paper, etc).

Table 6. Number of students by sex enrolled in $8^{\text {th }}$ grade and percentage that passed BEPC Source : CEG de Guiba, juin, 2008 [5]

\begin{tabular}{|c|c|c|c|c|c|c|c|c|c|c|}
\hline School Year & \multicolumn{2}{|c|}{ 2003-2004 } & \multicolumn{2}{|c|}{ 2004-2005 } & \multicolumn{2}{|c|}{ 2005-2006 } & \multicolumn{2}{|c|}{ 2006-2007 } & \multicolumn{2}{|c|}{ 2007-2008 } \\
\hline Gender & M & F & M & F & M & F & M & F & M & F \\
\hline $\begin{array}{c}\text { Number of } \\
\text { students }\end{array}$ & 114 & 83 & 118 & 108 & 143 & 101 & 147 & 115 & 152 & 122 \\
\hline Total & \multicolumn{2}{|c|}{1997} & 226 & 244 & \multicolumn{2}{|c|}{262} & \multicolumn{2}{|c|}{274} \\
\hline $\begin{array}{c}\text { Passed } \\
\text { BEPC }\end{array}$ & \multicolumn{2}{|c|}{$91 \%$} & $67,74 \%$ & $76 \%$ & \multicolumn{2}{|c|}{$49 \%$} & \multicolumn{2}{|c|}{$78 \%$} \\
\hline
\end{tabular}

The quality of infrastructure in the commune of Guiba is acceptable although there is no laboratory and there is not enough places for teachers to lodge in the villages. This is one of the problems with finding teachers is that there are not enough classrooms for the teachers to work. This insufficiency is accompanied by a lack of latrines (one for two schools) and not enough clean water sources. The secondary school has four classrooms and has chalkboards in each classroom. There is one library, four buildings for classrooms, one administrative building, three buildings for teachers to live, two pumps for water and one latrine. Each classroom is supposed to hold a capacity of 70 students 
per class but, often for 6th and 7th grade, these class sizes are not obtained. In 2008 the class sizes were about 100 students per class in 6th grade and 90 students per class in 7 th grade.

\section{APPENDIX E: DIETARY DIVERSITY QUESTIONNAIRE}

Qu'est ce que vous avez mange hier?

\begin{tabular}{|c|c|c|c|c|c|}
\hline Le matin & Petite repas & Midi & Petite repas & Soir & Petite repas \\
\hline & & & & & \\
\hline & & & & & \\
\hline & & & & & \\
\hline & & & & & \\
\hline
\end{tabular}

\section{APPENDIX F: IRB APPROVAL FORM}

DATE:

TO:

FROM:

RE:

TITLE:

SUBMISSION TYPE:

STATUS:
May 13, 2015

Kristine Nachbor, clo Casey Huckins Biological Sciences Cheryl A Gherna, CIP, Coordinator Regulatory Review Boards

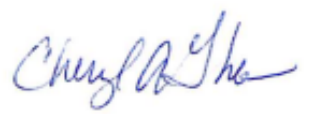

M1338, [726919-1]

REGIONAL PREVALENCE OF MALNUTRITION AND WATER BORNE DISEASE IN ADOLDOLECENTS DUE TO ENVIRONMENTAL INDICATORS OF WATER AND FOOD SECURITY

New Project

APPROVED, Exempt Status

Stipulation:

You are required to obtain and retain documentation, either a letter or email, from someone of authority at the school where this research will be conducted that acknowledges this research activity in the classroom and indicates approval to conduct it.

A written letter that acknowledges my research activity was obtained from the headmaster of the school Midon Coullbaly.

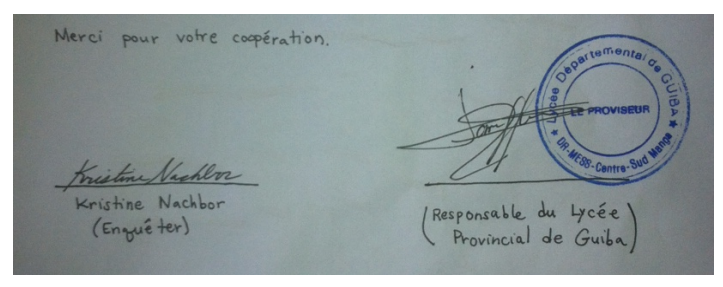

